\title{
ACHIEVING ACCOUNTABILITY THROUGH DECENTRALIZATION: Lessons for integrated river basin management
}

\author{
Jyothsna Mody
}

\begin{abstract}
While decentralization holds out the promise of increased flexibility and efficiency, the preconditions for realizing it are daunting. To draw lessons for productive decentralization in integrated river basin management, this paper surveys the decentralization experience in education, healthcare, roads, irrigation, and public infrastructure services. Case studies reveal that the prime focus in the design of a decentralized structure must be accountability, based on principles of subsidiarity, transparency, and allocation of property rights. While some debates are sector specific, others, such as the need for political and financial accountability, the related data requirements, educating stakeholders and potential beneficiaries of the new system, and ensuring effective participation, are true of decentralization wherever it is to unfold. In turn, initial conditions and the adaptation of political leadership to suit the historical context determine the success of decentralization. Four issues demand high priority in integrated river basin management. These are: (1) overcoming financial inadequacy at the lower levels; (2) commitment to upgrading skills, particularly management skills, while also ensuring that the expertise accumulated in central bureaucracies is not dissipated; (3) assuring pre-reform beneficiaries that their rights would be protected; and (4) sustaining a long-term commitment to an inevitably slow and drawn out decentralization process. The main conclusions of the literature survey caution those who believe that decentralization is, in itself, a solution to problems of inefficiency and inequity in developing countries. Trade-offs and tensions need to be reconciled (e.g., economies of scale versus local monitoring; integrated management or inter-regional equity versus local control).
\end{abstract}

World Bank Policy Research Working Paper 3346, June 2004

The Policy Research Working Paper Series disseminates the findings of work in progress to encourage the exchange of ideas about development issues. An objective of the series is to get the findings out quickly, even if the presentations are less than fully polished. The papers carry the names of the authors and should be cited accordingly. The findings, interpretations, and conclusions expressed in this paper are entirely those of the authors. They do not necessarily represent the view of the World Bank, its Executive Directors, or the countries they represent. Policy Research Working Papers are available online at http:/ / econ.worldbank.org.

\footnotetext{
1 This paper is part of the study, "Integrated River Basin Management and the Principle of Managing Water Resources at the Lowest Appropriate Level - When and Why Does It (Not) Work in Practice?" The project is being carried out by the Agriculture and Rural Development Department at the World Bank. Additional support has been provided by the Water Resources Management Group and the South Asia Social and Environment Unit at the World Bank. Useful comments by William Blomquist and David Mosse are acknowledged. Valuable suggestions provided by Karin Kemper and Ariel Dinar are also recognized.
} 


\section{TABLE OF CONTENTS}

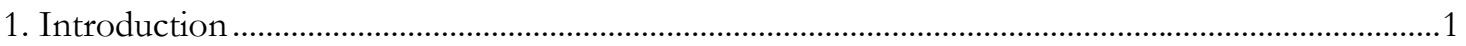

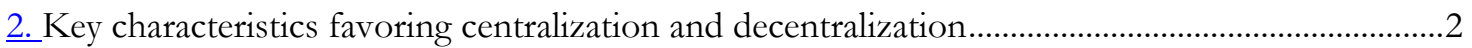

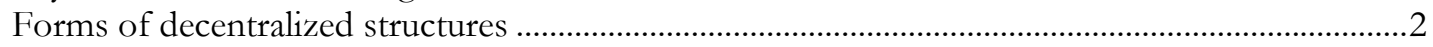

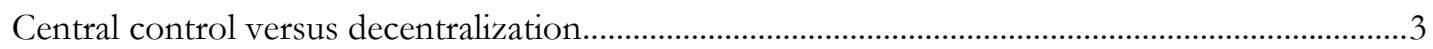

3. Management of river basin systems through decentralization.....................................................

Objectives of integrated river basin management..........................................................................

Centralization and decentralization in river basin management ........................................................ 9

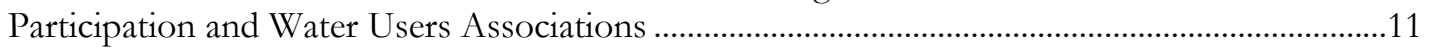

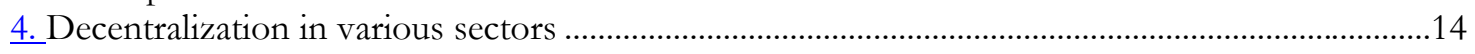

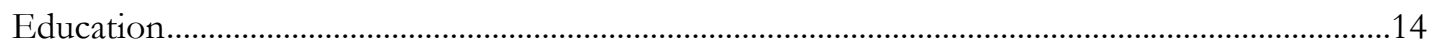

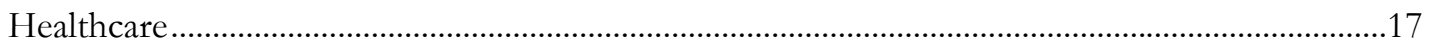

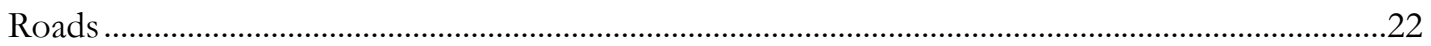

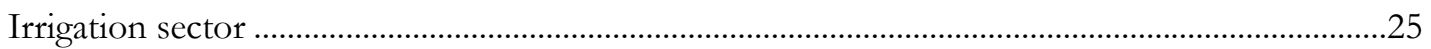

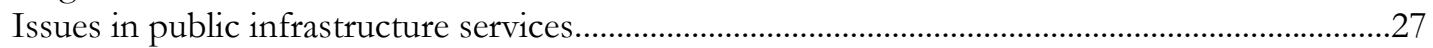

5. Equity, capture by local elite, and lessons for infrastructure delivery.............................................28

6. Decentralization Design: select issues for integrated river basin management...............................29

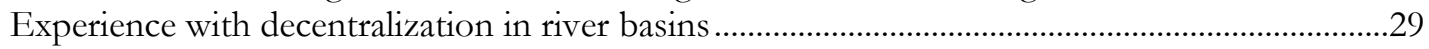

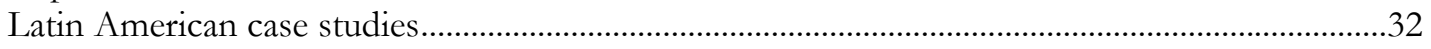

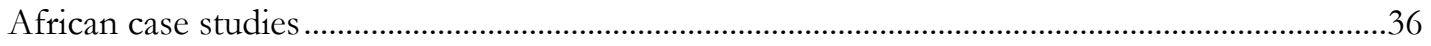

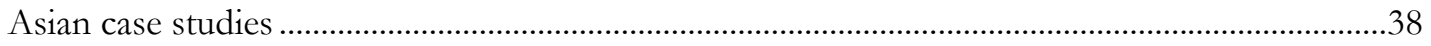

7. Lessons learned from other sectors relevant to river basins .............................................................40

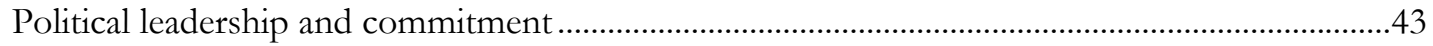

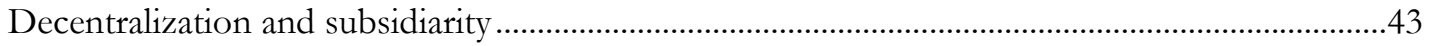

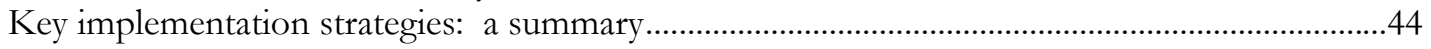

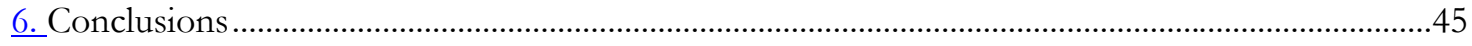

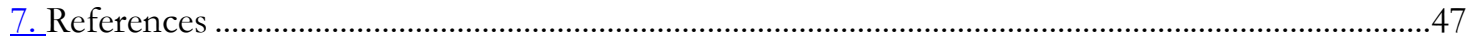




\section{INTRODUCTION}

Decentralization is a process of transitioning from a governance structure in which power is concentrated at the central or national level to one in which the authority to make decisions and implement them is shifted to lower level governments or agencies (including parastatal organizations). The resulting governing structure is anticipated to deliver public services more efficiently and equitably. Because of proximity to the locus of action, decentralization offers the prospect of lower transactions costs and the generation of information most relevant for serving the consumer of public services. As such, it is expected that decision-makers at decentralized levels may be held accountable for the outcomes of their actions, and for this reason are more likely to be motivated than the anonymous bureaucrats in the central government.

The principle of decentralization has acquired increasing prominence in a variety of development activities, as also in the management of river basins. Although river basin decentralization is expected to benefit the people residing and operating within the ecological area, case studies point to mixed results. For example, greater efficiency with respect to storage capacity and power production can result where decentralization allows upstream and downstream hydropower producers to negotiate the quantity of flow of water in the river. On the other hand, since all issues of allocation cannot be resolved through negotiation alone, as with priority rights among competing users of river water, the intervention of a higher level of authority may be necessary and decentralized river basin management is less effective (Wandschneider, 1984). Successful decentralization depends on negotiated voluntary arrangements, conflict resolution mechanisms, and the institutions necessary to support them.

To draw lessons for productive decentralization in integrated river basin management, this paper also examines the decentralization experience in several other sectors: education, healthcare, roads, irrigation and water supply, electric power and antipoverty programs. Because significant decentralization efforts have been undertaken in these sectors, they are relevant for the present discussion. Recent analyses have focused on the problems faced in achieving effectively functioning decentralized operations while also proposing the measures to overcome them.

Viewed from a technical perspective, the allocation of certain tasks to particular levels of government is relatively uncontroversial. For example, Prud'homme (1994) suggests that redistributive actions are likely to be more effective when taken by the center. Similarly, in analyzing democratic decentralization in the state of Kerala (India), Sharma (2003) observes that local level planning energized attention to basic needs issues, such as housing, animal husbandry, and drinking water but could not address external effects on the local economy, such as falling prices of cash crops and unemployment. Proponents of decentralization argue that such decisions as the design of schooling facilities, the schedule of instruction, and staff assignment to teaching courses are most efficiently taken by the school principal or a committee comprising parents and staff.

However, because decentralization depends on a complex set of organizational and financial measures, the most effective approach to it is not always straightforward. As an example, the provision of a new road involves several tasks, such as determining its location and design, identifying the target group of beneficiaries, procuring finance, awarding construction contracts, and determining the proportion of costs to be recovered and how to recover them. These tasks may be allocated to different levels of government in several ways. Moreover, because the technology of service delivery differs across infrastructure and social sectors, strategies for decentralization need to be adapted to these variations. 
While the allocation of particular tasks across levels of governments must take into account the specificity of the sector, certain management principles, nevertheless, apply across sectors. A review of the literature points to common themes for successful decentralization. First, the bistorical context and initial conditions, including geographical and climatic features, existing patterns of service provision or traditional methods of addressing the user's need, and economic conditions significantly influence the pattern of decentralization. Second, political leadership is key to overcoming the implementation hurdles that arise in the transition to decentralization; these include: (1) inadequate financing; (2) paucity in skills, particularly with respect to management and supervision; (3) resistance from those who benefit from the centralized structure; (4) how to sustain interest in the participatory process for the long term. Leadership is also critical to ensuring that administrative, political, and fiscal decentralization operate in tandem.

The prime focus in the design of the organizational structure is accountability, which may be achieved through decentralization based on principles of subsidiarity, transparency, and allocation of property rights. These, however, are abstract concepts and their implementation is determined by the initial conditions. Successful application of the principles depends on how well they are tailored to suit the historical context. It is to carry out this adaptation that political leadership is essential in the pursuit of accountability.

The rest of the paper is organized as follows: the next section presents the key characteristics favoring centralization and decentralization, defines some of the forms of decentralized structures, and briefly describes multiple, and complementary, facets of decentralization to support efficiency and equity; The third section discusses the relative roles of centralized decision making and decentralization in the context of river basins. The fourth section reviews decentralization in other sectors to draw lessons for river basin management. The fifth section highlights equity issues. Select issues relevant to integrated river basin management are described based on case studies in the literature in the sixth section. The seventh section summarizes lessons learned in light of experiences in other sectors, and the final section pulls together the main findings of the paper.

\section{KEY CHARACTERISTICS FAVORING CENTRALIZATION AND DECENTRALIZATION}

Decentralization involves a redistribution of authority and allocation of resources with more power being shifted away from the central or national level to lower levels of government. The lower levels vary across countries and across sectors. Generally, in nations which have federal structures they consist of state or provincial governments, and municipalities or districts within them. There are other examples, such as the village Panchayats in India or Upazila Parishads in Bangladesh (Ahmad, 1992). Levels may even include a river basin organization as in the water sector or a school as in the education sector.

\section{Forms of decentralized structures}

In many cases, decentralization is initiated as a matter of national policy followed by implementation of necessary structural changes also by the central government, as has been the case in Mexico, Brazil, and Papua New Guinea to cite a few examples. Under this scenario, the lower level of government becomes responsible for the delivery of public services, with some sectors being more decentralized than others.

Administrative decentralization can take place within an organizational or in a socio-political context. Functions are said to be deconcentrated when some of them are shifted within an organization, as from the center to field offices at lower levels. In this case, either all authority is centralized or some flexibility is allowed so that field offices can adjust central plans to suit local conditions. Alternatively, the local government is responsible for delivery of services under central guidelines and supervision. This is essentially an administrative restructuring but maintaining central control. For 
example, district committees in Sri Lanka are provided funds to manage services locally. A different kind of structure that aims to facilitate local coordination is an integrated model in which local bodies may plan and implement programs but may not raise the necessary revenue to run them. In this instance, these bodies do not constitute an independent local government. They continue to receive policy and technical advice from the ministries.

Sometimes authority to make decisions is delegated to independent corporations or agencies who also manage specific functions. These may include revenue collection and allocation, and construction and management of infrastructure undertakings, such as dams, school buildings, and roads.

When local communities, in geographically delineated areas, manage their own necessities by electing or appointing local representatives who function without direct central control then authority is considered to be devolved to that level. Devolution is more complete when local governments may also raise revenue and decide on expenditures based on local needs. In Papua New Guinea the provincial government raises taxes to finance rural health services and simultaneously runs hospitals for the national government using grants from the center.

The above definitions found in the literature (Ahmad, 1992; Mills et al., 1990; McGinn and Welsh, 1999; Shah and Thompson, 2002) are meant to describe the nature of reorganization under decentralization but different forms and combinations may coexist depending on many factors. These include historical context and initial conditions, geographical features particularly the size of the country and objectives. For example, the community may demand equity even at the expense of some efficiency or vice versa. In areas of West Bengal, India, farmers preferred public regulation of water markets by village panchayats (local governments) who set price ceilings to prevent price discrimination by monopolists, owners of large tubewells who exploited small farmers (Rawal, 2000). In the democratic decentralization movement (People Planning Campaign) in Kerala, community participation, local governance, and equity are the deepest concerns when making choices in healthcare and education (Elamon and Ekbal, 2000; Ganesh and Ramakrishnan, 2000; Tharakan, 2000). In this case, it appears that the criterion for success in decentralized organization is whether the system works and not because it is the most efficient.

\section{Central control versus decentralization}

The essential trade-off is between efficiency achieved through economies of scale that favors centralization and efficiency and equity benefits through local or decentralized decision-making (Besley and Coate, 1999).

\section{Technological economies of scale}

Technological economies of scale are a key justification for centralization. Such scale economies vary considerably by sector and within sectors by type of activity. There is also some evidence that scale economies have declined recently in infrastructure sectors, like power and telephony, due to technological innovations (Estache and Sinha, 1994; World Bank, 1994) thus weakening the case for central control.

Decentralizing public services with economies of scale is more difficult to justify on the basis of increasing efficiency unless the welfare losses are low enough that they can be overcome or compensated for in gains somewhere else (Prud'homme, 1994). In the rural road sector in Zambia, neighboring communities are considering joint arrangements to enhance the scale of projects to attract private contractors (Robinson and Stiedl, 2001).

In addition to technological economies of scale, central control is justified by such regulatory and administrative considerations as: inter-jurisdictional externalities, planning (as in designing an electricity transmission grid or locating hydroelectric plants), and certain regulatory functions such as price setting. Several studies emphasize the need for a balance between centralization and decentralization, by reminding reformers of the crucial roles played by a central authority (Humplick and Estsache, 1995; Kleemeier, 2001; Prud'homme 1994; Rodinelli and Nellis, 1986).

\section{Transaction costs}

Proponents argue that a key efficiency gain from decentralization is lower transaction costs. This may occur for a variety of reasons. Availability of better information at the local level with regard to 
feasible technologies and the specific needs of customers, where properly used, can improve efficiency. A related gain is greater accountability when responsibility for decision-making and implementation of programs is placed in the hands of local leaders. Participation at the local level can also improve skill levels and through this and other mechanisms enhance equity (Ahmad, 1992; Bardhan, 1996b; Besley and Coate, 1999; Conyers, 1984; Devas, 1997; Litvak and Seddon, 1999; Tommasi and Weinschelbaum, 1999).

Sharma (2003) presents an interesting picture of the reality on the ground. Public perception indeed agrees with the notion that local planners are more in tune with issues important to them and this is evident from the attention paid to basic needs, such as housing, roads, water, and vegetable farming. However, many project proposals were not the product of deliberation and solutions based on local level know-how. In fact, proposals followed suggestions from handbooks, there was little financial analysis and a tendency to continue on-going schemes in various government departments. This occurred due to a shortage of expertise and also the belief that those proposals were more likely to be approved and funded by policy makers. While one might concur with the idea that skill levels will improve through participation this is unlikely in the short run but could be a likely outcome in the long run due to training programs and from working alongside state level experts assigned to the projects. All this means increased expenditure. Additionally, there are training programs for resource persons who mobilize and conduct meetings, allowances and honoraria paid to new appointees (panchayat staff and committee members) and the cost of organizing meetings themselves. In practice, the net effect on transaction costs is not so obvious.

\section{Equity}

The reasons put forth for decentralization include reduction in public spending (at least for the central government), increase efficiency in resource utilization, and more efficient management of public service delivery. Decentralization is also espoused as a principle because it is meant to give people the power to influence decisions that directly affect them. This last concept is appealing especially to adherents of "democratic decentralization" and "people's power" (Sharma, 2003; Isaac, 2000). They see decentralization as a way to enforce accountability. National governments themselves view decentralization as a mechanism that will attract and employ resources other than those available to them, in the provision of public services. However, since the distribution of wealth and skills is not uniform across all regions and localities, large disparities in services are likely to emerge.

Prud'homme (1994) argues that the central government is in a better position to reduce interregional disparities through transfers built into the national budget. Redistribution of incomes among households within regions, by local governments, is unlikely to reduce the differences between regions since the treatment of households with similar incomes would vary among regions. If the center's redistributive function is weakened through decentralization then interregional inequalities are likely to persist and may even increase in the long run. The central government can perform its redistributive function provided it retains sufficient control of taxation and expenditure policies.

While decentralization of infrastructure and social sectors is popular in many areas of the world, there are some inherent obstacles in implementation. Bardhan and Mookherjee (1998, 1999, 2000a, 2000b) have expressed the view in several studies that the institutional structure for local accountability is not already in place in developing countries and unless the local power structures are changed by some means, infrastructure delivery could be diverted to local elite who capture the government or agency.

Respondents to a survey of people's perception of decentralization in Kerala (Sharma, 2003) complained of beneficiary selection along political or family lines. Some respondents interviewed in the case study perceived local leaders to be no different from centralized agencies and felt that the new system did not bring any real benefit. The same survey, however, also found that in spite of the complaints against beneficiary selection, overall, local governments (panchayats) were still viewed as being more aware of the needs of the poor. 


\section{Accountability}

Accountability has political and financial dimensions. It is about whether decisions are made to address local preferences and needs and whether the mechanisms, such as the electoral process are effective in signaling voters' views. In the Mexican context, Greffe (1998) speculates if one-term tenure for an elected official is sufficient to indicate either approval or disapproval of the performance of elected officials. Accountability is also about the successful collection of revenues and subsequent use of public funds, which in turn requires financial information. Bird (1994) suggests regular financial reporting both to the local users and to independent audit agencies. In particular, central evaluation could be exercised by renewing financial commitments or approval for borrowing from capital markets based on past performance.

Realizing accountability depends on the quality of supporting institutions both to enforce fulfillment of commitments to local beneficiaries, for conflict resolution, for financial accounting, and for technological assistance and expertise.

\section{Conflict Resolution}

Conflict resolution is essential to reduce transaction costs and for any progress to be made under decentralization. Conflicts under decentralization may occur in several different contexts. The case study in Kerala (Sharma, 2003) suggests some of these. The administrative structure at the local level (panchayat) consists of elected bodies called panchayats at the level of the village (grama), the district, and the block. The grama sabha refers to the people in the process of planning. In addition there are a host of volunteer and other staff and committees of experts to take on various tasks.

Among these are trained resource persons who organize and conduct group discussions at meetings. Against this background, the major source of conflict arises when resource persons and members of implementation committees are selected based on political affiliations. One of the expectations of decentralization is that slow progress due to divisiveness at the state level could be avoided if some issues are directly dealt with at the local level. However, joint commitment on issues affecting the village as a whole is derailed when political or religious differences underlie discussions rather than the merits of the case. Besides, power may be centralized within these structures and their functioning may be counterproductive to the objectives of decentralization.

Another source of tension is between politicians and bureaucracies at the state level and local level agencies. State level expertise is sorely needed at the local level but at the same time officials and politicians from the centralized structures do not want to give up their power and want to strike a bargain. For example, members of legislative assemblies demanded separate constituency development funds hoping to maintain their power by controlling some of the funds earmarked for projects proposed through the local level procedures. Simultaneously, local level activists had difficulty understanding financial statistics and deciphering what level of funding was to be devolved to them.

Conflicts arise when experts are called in to approve of the technical aspects of projects, and they are viewed as encroaching on the rights of elected bodies. A similar situation can arise when there is a lack of expertise in fiscal management at the local level. Again, in Kerala, the state level agencies managed cash outflow and revenue collection while the panchayats were expected to account for expenditures. However, it was found that pancahyat secretaries were unable to provide accounts. Locals were not comfortable with the appointment of "implementation officers" to help with the accounting as they felt that they were giving up some control over their funds (Sharma, 2003).

Differences arise between state level planning and local level planning due to divergence in priorities. Further, when funds are transferred for state sponsored schemes there is a reluctance to integrate plans being drawn up locally into projects drawn up by the state agencies.

Sharma (2003) illustrates the link between conflict resolution and accountability in the case of a panchayat where a disagreement in the first meeting resulted in a cancellation of all future meetings. The question that arises is who is going to intervene and ensure that the local bodies are accountable to the citizens they serve and therefore obligated to convene and continue discussions? This highlights the need for supporting institutions that can perform functions that are parallel to what the judiciary, press, and legal system do at higher levels of government, at the local level. Supporting 
institutions may also have to be those that can provide technical assistance in order to help choose among competing proposals based on their feasibility.

The state has a key role to play in facilitating the decentralization process through initiating forums for discourse, establishing financial guidelines, capacity building, setting a timetable, legislating and setting up advisory bodies and resource institutions that are interested in local problems and finding solutions that work locally.

In the context of river basin management conflicts arise among competing users of the water in rivers and in a decentralized management structure these have to be resolved through negotiation. Wandschneider (1994) argues that negotiation is effective when there are clearly defined property or priority rights. If this is not the case, then a higher authority would have to intervene to defuse the situation.

\section{Technical expertise}

Under centralization, large investments are made in central bureaucracies in research and development. Qualified people, interested in public service are drawn to these bureaucracies in the hope of superior career prospects, varied job opportunities, and better resources. With decentralization, the accumulated pool of expertise is dissipated because the roles of central bureaucracies are shrunk and there is job loss. It is unclear whether the associated loss in efficiency can be made up by local governments or even by the private sector given the smaller capacity and shortage of skills at the local level and the uncertainty of the private sector being able to mobilize the kind of investment that central governments can.

Shortage of technical expertise at the local level is not only crucial to successful decentralization but also draws attention to the fact that there are limits to what can be expected of local bodies and has long term implications from a central perspective (state, regional or national). For example, (Sharma, 2003) describes how local agencies (grama panchayats in Kerala) are capable and motivated when it comes to dealing with problems relating to people's basic needs especially since these issues also enjoy the involvement of citizens and tend to make the exercise successful. (In fact, in a survey of public opinion, the success of local planning rested largely on whether the basic needs problems had been addressed and resolved as against reduction of corruption and quicker action). While this in itself is progressive, the question that arises is what the choice of projects means for long-term economic growth and development as priorities in local plans are markedly different from those of central schemes. Investment is shifted away from large and medium industry and power generation projects to the small-scale sector. Further, when project proposals are of poor quality due to lack of expertise, financial institutions are reluctant to provide credit.

At the same time decentralization could not address problems that affected the local economy critically but were beyond their control. The case study involves a state whose economy is dependent on remittances from labor employed overseas. Declining demand overseas for local labor and the effect on local employment could not be addressed by decentralization and describes a situation where central (state government) intervention was clearly necessary.

\section{Service provision}

Services, such as, power production and roads, requiring advanced technical expertise, management and administrative skills are less suitable for efficient local production than, for example, solid waste management. Technological advancements allow vertical disintegration (unbundling) in each sector permitting some aspects of service provision to be local while others are central. Thus, while garbage collection is not technically complex and can have efficiency gains from local provision, garbage recycling or processing requires more advanced skills. Where there is greater potential for competition, there is less need for regulation. So, factors affecting competition determine whether regulation in the sector is more efficient locally or not. The greater the economies of scale and dependence on expertise lower the potential for competition and the less likely that regulation can be handled locally. On the other hand, if information about local conditions and more direct monitoring are important in the sector then local regulation may be preferable (World Development, 1994). Water production is more technically sophisticated and has greater economies of scale thus requiring more regulation than local water distribution which is less complex. 


\section{Financing of services}

Generally and especially in developing countries, the tax base on which local governments depend is insufficient to cover expenditures. This implies that local governments depend on transfers from the center. Central governments can use transfers to induce a level of service or to work jointly with local governments to take advantage of economies of scale. Transfers, however, do not enhance allocation efficiencies because they distort decision-making.

Some services like water and power can be financed through user fees and are easier to decentralize in some aspects. However, garbage collection is not easy to charge based on the quantity of garbage and is financed through taxes. Services like education and health have to be financed by both fees and taxes. This is because the central government is interested in maintaining uniform standards of service and there are important externalities. Local governments have significant stakes in extending coverage of good quality education or health to all those in their jurisdiction because there are significant consequences for the local economy. A high degree of dependence on central transfers or taxes and a relatively weak local tax base make it difficult for services supported by taxes to achieve efficient production or allocation. Bird (1994) observes how local governments prefer to substitute new construction for maintenance of deteriorated facilities in response to availability of national funding for infrastructure investment but not for operation and maintenance.

Large size and income of countries are factors conducive to successful decentralization (Mills et al, 1990; Prud'homme, 1994). Bird (1994) expresses similar ideas in terms of the "spatial concentration of beneficiaries". The population, economic activity and tax base at the lower level has to be large enough to allow efficient production of the service but small enough to achieve the information, participation, and accountability improvements. Transferring authority to set and collect fees to small weak governments is unlikely to produce any efficiency gains. The idea is to balance the power between the central and lower levels in such a manner as to retain a central government that is strong enough to perform its duties and at the same time to transfer authority to local governments which have the ability to use that power efficiently. In large countries it is possible to establish special semiautonomous agencies to manage specific functions. For example, the River Basin Authorities in France are responsible for management of water resources. These agencies have the power to set water rates and pollution taxes and to collect the proceeds. They may also utilize the revenues for water production and treatment programs. The decentralizing of regulation also benefits large countries rather than small ones because the costs and skill requirements of establishing multiple agencies may take away efficiency gains in small countries (World Bank, 1994).

It is more complicated to decentralize and finance infrastructure sectors with spillover effects and substantial negative or positive externalities than others. For example, highways, telephones, power production, water production, and transportation are all services that involve large networks that have externalities for neighboring districts. On the other hand, decentralizing more localized services with few externalities, such as, ports or urban transport, and water distribution is likely to be feasible and achieve efficiency gains. Akin et al. (2001) study local government budgeting decisions under decentralization in Uganda by analyzing district level health budgets. They find district planners allocated declining amounts to public goods and services relative to private goods. They conclude from their data that spillover effects from neighboring districts influenced planners to adjust their health budgets downwards.

The functions within each sector have to be shared among central, regional, and local governments to enhance overall efficiency. In general, capital infrastructure investments and design, and auditing are more efficient under central control. Other functions that are more dependent on local information and subject to local accountability, such as, design selection and who should benefit from it, collection of fees, operation, maintenance and sometimes monitoring and regulation, setting of standards and addressing complaints from users can all be decentralized with adequate training or through contracts with private providers wherever feasible. Greffe, (1998) suggests that in the Mexican context, municipalities should be responsible for local distribution networks and policy in functions such as water supply and waste disposal, street cleaning, and electricity distribution; states should co-ordinate and manage activities undertaken by the municipalities including redistributive 
and spillover effects across municipalities; with the federal government in charge of services that have nationwide externalities and efficiency implications, as with regulating standards and redistributive functions across territorial units.

\section{MANAGEMENT OF RIVER BASIN SYSTEMS THROUGH DECENTRALIZATION}

The concept of integrated river basin management has its roots in a collective effort "to make water use economically productive, socially equitable and environmentally sustainable" for all users within the basin (Alaerts and Le Moigne, forthcoming). The river basin suggested a natural unit, due to its hydrological interconnectedness, within which to coordinate all decisions relating to achieving these goals. Acceptance of the physical unity of the river basin is central to sustaining the ecosystem while also facilitating economic growth and human welfare through an integrated approach (White, 1998; World Bank, 1993a). The Dublin Statement of 1992, demands a holistic approach to management of water resources, linking social and economic development with protection of natural ecosystems and also linking land and water uses across an entire catchment area or groundwater aquifer. The call for integrated management of water resources was further endorsed in Agenda 21 at the United Nations Conference on Environment and Development at Rio de Janeiro in 1992. This holistic approach thus entails greater integration and centralized decision making in certain dimensions while competition for resources within the basin makes feasible and increases the desirability of decentralization and stakeholder participation.

Awareness of diversity is critical especially when explaining the outcomes of different river basin projects and also when formulating policy. Characteristics of river basins vary considerably and overriding priorities to be tackled in one instance may differ from those in another. The size, topography, and hydrological features are some of the physical differences that must be recognized across river basins. But, in addition, economic and social elements vary across river basins. The region's degree of economic affluence determines its ability to attract federal attention and resources and the distribution of assets within the region conditions the access to water resources and the extent to which different stakeholders can voice their interests. In addition, traditional community structures and practices are likely to influence the choice of governance structures.

\section{Objectives of integrated river basin management}

Primarily, coordination of multiple activities and resolving conflicts, particularly those stemming from negative externalities are the key functions of integrated river basin management. These are in addition to the traditional objectives of allocation of water, supply, waste treatment, and water quality maintenance. These activities involve financing and development of infrastructure in a manner that ensures sustainability of the ecosystem and therefore, of water.

Alaerts and Le Moigne (forthcoming) present an overview of organizational models adopted by a number of river basin organizations. While they report over twenty different models in existence, they may be classified roughly, as those that are large organizations which perform planning, regulatory, and operational functions involving infrastructure, and those that are small agencies concentrating on planning, policy, and coordination only. Models differ for example, in the extent of the role played by the central government, in whether they undertake operations or not, and in the specialized tasks they are entrusted with. For example, the Mexican Water Councils report to and are supervised by the National Water Commission, the central agency. In the Australian Murray-Darling basin, the governments of the riparian states carry out operational duties while The Murray-Darling Basin Commission coordinates inter-state planning and policy. The Tennessee Valley Authority is responsible for hydropower in its jurisdiction.

It is important to reiterate the point made in section 2, that decentralization even within river basins is not a simple or monolithic concept. In different contexts, the specific rationale for decentralization also guides the appropriate form of decentralization. First, administrative decentralization delegates authority to lower levels of government, from federal to state and from state 
to municipal authorities. Second, devolution may include the establishment of formal water users' associations that participate in official monitoring and regulatory functions. In this form of participation, water users play the role of protecting their rights, ensuring, for example, that prices charged are fair and/or water quality standards are being respected. Third, in addition, participation can be more far reaching, as, for example, when stakeholders are engaged directly in the process of managing resources and delivering services-Ostrom (1996) refers to such participation as "coproduction" (see also Evans, 1996 and Lam, 1996 for the analysis of coproduction).

With respect to administrative decentralization, again, the key objective is to achieve greater bureaucratic efficiency. As Alaerts (1999, p. 18) notes:

"In a world with more competition for scarce water, water management organizations shift from a top-down hierarchic bureaucracy model into clusters of complementary flexible task-specific organizations that are managed like enterprises aiming at achieving pseudo-commercial goals, and that are more demand-responsive."

Examples of such bureaucratic entrepreneurship and flexibility do exist. In the context of irrigation bureaucracies, Wade (1997) concludes that Korea's more user-friendly bureaucracy compared to the more rigid and unresponsive systems in India helps explain some part of Korea's greater gain in agricultural productivity. But having recognized such important differences, the task of changing bureaucratic structures tends to be an extremely demanding one. Such institutional engineering, Alaerts (1999) concludes, often requires decades for successful implementation. For example, the "paragon of modern-day river basin management," Australia's Murray-Darling Commission took almost 80 years to begin functioning effectively as conflicts persisted between riparian states. In addition, decentralization, to be effective, has to be accompanied by financial autonomy, which often requires considerable institutional reform and, in particular, the establishment of some form of (possibly, modest) water pricing.

\section{Centralization and decentralization in river basin management}

Is the lowest appropriate level of management in a river basin, a central agency like the river basin authority or a sub-basin entity like the water user association? In practice centralization and decentralization are not dichotomous choices. Rather, most systems are likely to lie along a spectrum between the two extremes. However, for the purpose of clarifying the underlying concepts and highlighting the relative importance of alternative strategies, Table 1 below suggests a scheme for linking the decentralization/centralization decision to the objectives of river basin management outlined above.

Table 1: Linking the decentralization decision to river basin objectives

\begin{tabular}{|l|l|l|l|l|l|}
\hline & \multicolumn{5}{|c|}{ OBJECTIVES } \\
\hline & $\begin{array}{l}\text { Efficient } \\
\text { water use } \\
\text { water quality }\end{array}$ & $\begin{array}{l}\text { Management oquity in } \\
\text { access } \\
\text { water }\end{array}$ & $\begin{array}{l}\text { Preserving the } \\
\text { ecosystem }\end{array}$ \\
\hline $\begin{array}{l}\text { Centralization (as in a river } \\
\text { basin authority) }\end{array}$ & $\sqrt{ }$ & $\sqrt{ }$ & & \\
\hline Decentralization water users' & $\sqrt{ }$ & $\sqrt{ }$ & $\sqrt{ }$ & \\
\hline $\begin{array}{l}\text { Formal } \\
\text { associations }\end{array}$ & & & $\sqrt{ }$ & \\
\hline $\begin{array}{l}\text { Informal stakeholder } \\
\text { participation }\end{array}$ & & & & \\
\hline
\end{tabular}

Centralization in the river basin helps achieve coordination of infrastructure, human resource development, and the setting of general priorities for water allocation, water quality, and land-use. 
Central authority is also needed to set standards, both of a technical nature and those that relate to establishing accountability.

The potential for economic efficiency of centralized management of river basins arises from their special economic characteristics. These include, as Wandschneider (1984) notes: (a) indivisibility of investment projects, especially those for dams and storage; (b) hydrological externalities, e.g., downstream users depend on upstream actions; and (c) the public good nature of the river basin infrastructure, e.g., flood control infrastructure can be used by all without reducing the benefits of other users and exclusion of users from the right to use is also severely limited. Therefore there are market failures and it is conceivable that a central agency with jurisdiction over the whole river basin is a suitable management organization. Such a system can take advantage of economies of scale in large projects, internalize externalities, and manage the hydrological interconnectedness.

The case for centralization also appears in the public administration literature where fragmented administrative structures are thought to suffer from duplication, the lack of coordination, and lack of accountability (Bish and Ostrom 1973 summarize and critique this literature). Once again, the recommendation is for a central public management agency, such as the Tennessee Valley Authority. Thus, both economic and public administration logic can serve to support the goal of "integration" through a central agency in river basin management.

However, centralization suffers from the disadvantage of "bureaucratic cumbersomeness and slow response" (Chioccioli, Hamdy, and Lacirignola, not dated). In his review of river basins, Barrow (1998) cites evidence that river basin authorities tend to be "inflexible" and "over-ambitious." In particular, centralization is ill-suited to resolve conflicts among diverse stakeholders and is ill-suited also to harness the local traditions and knowledge that are often essential not only for raising productivity of water use but also, and perhaps more importantly, for sustaining delicate ecosystems. In principle, appropriate decentralization can achieve efficiency gains through more effective delivery of service to users and also through more prudent use of local resources and initiative. Decentralization can be the definitively superior approach where institutional arrangements also help achieve the coordinating function of centralized systems. Wandschneider (1984) cites the ColumbiaRiver system as evidence that a polycentric or a pluralistic distribution of authority can be effective and a centralized system is not the only way that market failures can be overcome.

However the outcomes of a decentralized structure would differ from those arising from central control (Wandschneider, 1984). By choosing between decentralization and centralized systems one is also choosing between unanimity and majority rules and this determines whether all stakeholders benefit or some groups are marginalized. In the decentralized-negotiation approach the principle of unanimity allows each right-holder a veto, implying that a change from the status quo is possible only when the new option is a win-win situation for all stakeholders. Under majority rule, that is, when the national government is elected to power and uses its authority to make policy decisions, then the choice is neutral between alternatives. The option preferred by the majority (assuming they are the most powerful groups) is imposed on the minority even if they are opposed to it and takes the right to a solution that best addresses their preferences away from them.

Negotiated outcomes necessary for decentralization, however, can only be successful when property rights are well established. Wandschneider (1984) notes that along the Columbia-Snake River System, fishermen were able to negotiate with hydropower utilities only when property rights in fishing were established. But conflict between instream users (principally hydropower utilities) and irrigators remained because instream rights remained unclear. Thus decentralization risks the danger of raising transaction costs ${ }^{2}$ where functions overlap across agencies and users are poorly organized

${ }^{2}$ Use of instream water is both non-exclusive and fugitive. That is, if water is available for one user to access it is available to all. For this reason, individual users do not have an incentive to demand a right on their own but would have to do so collectively to obtain one (Wandschneider, 1984) thus increasing transaction costs. 
to play their proper role. Ostrom (1990) also describes the challenges of achieving negotiated outcomes, using examples of groundwater basins from the south coastal plain of the state of California in the United States. However, while recognizing the importance of differing local conditions, she is ultimately more optimistic with regard to the prospect of negotiations leading to an efficient "self-regulatory" outcome.

\section{Participation and Water Users Associations}

User and other stakeholder participation can effectively complement administrative decentralization. Participation is sometimes described as providing a "voice" to stakeholders (see, for example, Narayan 1995). However, it is more helpful to think of participation as providing de facto property rights. In a situation where legal rights of individuals and households are ill defined, participation can be a collective mechanism of creating property rights, in the sense that it can establish (sometimes implicit, but real) claims on the use of assets or in the sharing of revenues. An aspect of the coordinating function that the government otherwise undertakes in a centralized structure is now to be managed by the stakeholders and users themselves. Viewed through this lens, participation can be critical to achieving coordination and, hence, provide significant benefits. Solanes (1998) refers to this "as a process of democratizing and balancing water decision-making and water-related activities". However, despite its potential, participation in the context of river basins has remained "too limited and narrow in focus" (Visscher, Bury, Gould, and Moriarty, 1999). Mechanisms to achieve greater participation are poorly understood. Moreover, not only are there significant challenges to achieving greater participation, but also there is at least some risk that the process of participation can be highjacked where diverse stakeholders have unequal bargaining power (see, for example, Koppel, 1987, Solanes, 1998, and Kemper and Olson, 2000).

Complex interactions also arise between self-organized, community-based watershed organizations and public agencies. Centralized agencies with their hierarchical structures and standardized operating procedures tend to be "unreliable partners" with local stakeholders (Thomas, 1999). In this respect, less structured, decentralized administrative agencies tend to be more responsive to stakeholder objectives. Lam (1996) notes, in the context of Taiwan, that bureaucratic agencies staffed by local population tend to be aware of local needs and can interpret official guidelines in a manner sensitive to local requirements (see also, Wade, 1997 for a similar argument in the Korean context). However, the very same features that lead to a successful public-private partnership also generate the possibility and perception of agency capture by local stakeholders (Thomas, 1999).

When is participation relevant? In the context of river basins, the most important role played by participation is in allocating water among multiple demands, such as hydropower, drinking water, irrigation, conservation, and a host of other sectors (Dourojeanni, 1994). Koppel (1987) stresses also the importance of user participation for improvement of performance and sustainability of investments made by area improvement programs. Ghai and Vivian (1992) highlight the importance of participation for the preservation of delicate ecosystems and, in particular, the benefits that accrue when traditional knowledge and practices are deployed. Agarwal and Narain (1999) also emphasize the critical importance of harnessing traditional techniques to collect water through village-based harvesting systems, whose viability has been undermined over time by centralized control; they argue that such "dying wisdom" may offer the best alternative to large dams and other water development projects to avert a water crisis in India.

How does participation occur? Participation occurs at different levels, either by dialogue among stakeholders such as hydropower utilities, federal, state and local government agencies, business representatives, agriculturists and users. It may also occur at the level of water user associations where users bound by a single purpose may organize themselves. Stakeholders may participate in workshops, through membership in administrative bodies or in public hearings. The lowest appropriate 
level of management in a river basin may be the river basin authority that invites participation or it may be a water user association that monitors, operates and manages a small-scale irrigation system. Some user associations with elected office bearers and perhaps a self-financing mechanism may be registered, while others are more informal. ${ }^{3}$ There is a wide variation in the function, structure, membership criteria, title to water rights, legal recognition, and the leverage they have with institutions at higher levels. Solanes (1998) cites an interesting example of how engineers, through the American Society of Civil Engineers, are actively engaged in drafting legal guidelines to integrated river basin management.

What are the benefits of participation? Cowie and O'Toole (1998) note that the benefits of participation are multifaceted. While the ultimate objectives are efficiency, equity, and sustainability, participation can help achieve these objectives through other channels such as, increased credibility and legitimacy, better information offering opportunities for innovative solutions more suited to local conditions, and joint ownership of results.

Recent studies, in quite diverse contexts, have indeed found that participation has a big impact on efficiency. The methodology usually analyses changes in baseline data, over a five to ten year period, using both qualitative and quantitative techniques (generally multivariate regression analyses). Data for these analyses is typically from primary surveys, often designed specifically to evaluate the impact of decentralization.

In a study of rural water supply projects, for example, Narayan (1995) finds beneficiary participation to be the single most important factor contributing to project effectiveness and sustainability. Other outcomes, such as, percentage of water systems in good condition, overall economic benefits, percentage of population covered, equality of access, and environmental effects also benefit from participation.

The impact of participation has also been assessed in watershed management projects in Nepal and Maharashtra, India, for example (Wagley, 1999; Lobo and Palghadmal, 1999). These analyses typically show large gains through participation. In the Nepalese case, community development conservation committees were involved in a variety of activities to increase agricultural yields. These included introduction of new seed varieties, the diffusion of agro forestry technologies, soil conservation (through the construction of embankments), planning, implementation, and maintenance of project activities. This wide ranging participation created not only short-term gains but also helped build capacity that allowed these gains to be sustained and enhanced.

Not all examples of participation are successful. Samad and Vermillion (1999) assess the impact of participatory management on the performance of irrigated agriculture in Sri Lanka. The program involved transfer of full responsibility for the operation and maintenance of several irrigation schemes to farmer organizations. The authors investigate whether participation reduced the cost to the government and to farmers, whether the quality of irrigation service improved, and whether agricultural productivity per unit of land and water was higher where irrigation management transfer occurred. The methodology compared performance indicators before and after transfer, and with and without intervention. The results were mixed. Over time, a significant decline occurred in government recurrent expenditures for irrigation in schemes where transfer had occurred; but expenditures also declined where there was no transfer to farmers' organizations. The cost to farmers remained the same following a transfer, but farmers contributed less in cash and more in labor. The reforms, by themselves, did not bring about significant improvements in the quality of irrigation levels, though a combination of transfer and physical rehabilitation did show increase in agricultural productivity.

${ }^{3}$ In the context of irrigation, the term "water users association" is a generic term for an organized group of irrigators with some involvement in irrigation management (Subramanian, Jagannathan, and Meinzen-Dick, 1997). 
Participation can, sometimes, even lead to undesirable outcomes. This occurs where there is severe inequality in stakeholder access to resources and hence to participation. As noted earlier, high levels of education and superior organization lead to more leverage for high-status farmers than is possible for poor farmers. Lack of available information, low social status, and the lack of economic strength are all related to low levels of participation-and to inefficient and iniquitous outcomes where participation is attempted in such contexts. Solanes (1998) describes how in a public consultation for water legislation in South Africa, responses were received from industry but no comments were submitted by rural communities and village-level water committees. Similarly, special interests can actively influence the choice of projects, which may sometimes have questionable economic benefits.

While most of the above examples demonstrate that participation can lead to better project outcomes, what do we know about how it occurs and how to achieve it? Currently, mobilizing coordinating councils in river basin management, water user associations in irrigation, and water and sanitation associations in that sector are the recognized methods. But that only pushes one to ask when do these associations work and not work? When are people willing to come together and when not? On that critical issue the understanding is much weaker.

Equity and accountability are extremely important in the water sector where decentralization is supported because it is believed that thus far disadvantaged populations will somehow also benefit from the resource. Legislation on property rights is one of the key aspects of reform to translate the above principles into practice because this defines the status of stakeholders, which in turn influences the success of participatory processes at the local level.

Derman et al. (2000) highlight these concerns in a study on water sector reform in Zimbabwe. Integrated water management in Zimbabwe is based on the catchment or watershed. A central organization, ZINWA, oversees Catchment and Subcatchment Councils, the former is responsible for planning and overall management while the latter have responsibilities ranging from water allocation, issuing of water permits, collection of data, assisting ZINWA with planning, and protecting the catchment. They also embody channels for stakeholder involvement. The Subcatchment Councils (SCCs) have fifteen members and all Subcatchment Councils are represented in the Catchment Councils (CCs).

As in other African countries formerly under colonial rulers, water rights in Zimbabwe, for nonprimary or commercial uses are linked to land ownership. More recent reforms are converting these permanent rights to permits which are issued are for specified time periods and purposes. The new Water Act has declared all water, surface and groundwater, public and attempts to address the water requirements of the disadvantaged users through stakeholder participation. An immediate problem to be overcome is that since many of these landowners were white farmers, the mostly black communal and small-farmers and primary water users, mostly women, are less likely to become permit holders and their participation is essential for decentralization to benefit them.

The study reports partial success. The drafting of the new Water Act of 1976 and the Zimbabwe National Water Authority Act that followed were based on dialogue with stakeholders. However, the stakeholders consisted mainly of large water right holders, professionals and businesses which had vested interests in the formulation of the new policy. Representation by small-scale, communal and resettlement farmers, is limited and raises equity concerns despite the formal establishment of councils. These users depend on water from sources, such as, borewells and small dams, which are not a major focus of reform. They are not a significant influential force because they are neither likely to be permit holders nor are they aware of new water laws and how they can voice their concerns. Similarly, the special interests of women, for example, for irrigating vegetables are barely heard.

Yet there has been progress in other areas. For example, the stakeholders were able to succeed in getting ZINWA, the central organization, to legislate that four of its twenty one board members would be representatives from the Catchment Councils (CCs) which embody channels for stakeholder involvement. In addition, a demand for another level below the Sub-Catchment Councils (SCCs) in order to reach people at the grassroots has been heeded and the associations are 
allowed to form although no specific functions have been assigned to them as with the CCs and the SCCs.

The appointment of the River Basin or Catchment Manager, to oversee the administration of the CCs, raises questions about accountability. The CCs can merely advice the manager but do not have any authority over the official or his staff. The manager is only accountable to ZINWA which in turn is accountable to the Minister. This suggests no real accountability to the stakeholders who elect Council members, who remain under central control though the manager.

\section{DECENTRALIZATION IN VARIOUS SECTORS}

This section summarizes decentralization in diverse sectors. The template consists of listing the main functions in each sector and discussing which functions are more likely to be decentralized or continued to be centrally controlled. The section will focus on implementation while presenting information, based on examples in the literature, on what is working and where the pitfalls are from the experience so far.

The following sectors have been selected because commitment to decentralization has been declared as a matter of policy in these areas in many countries. Intra-sectoral and intersectoral coordination is critical in health as it is in river basin management. Education is interesting to river basins because in pursuing decentralization, the sector is also making a break from the traditional emphasis on standardization in favor of one that discards the one size fits all approach and promises multiple solutions to meet assorted goals. Since river basins also differ in many ways, including size, aridity, availability of water, and hydrology to name a few, an understanding of the range of approaches in education may prove useful. As in river basins, roads are part of networks and both sectors have to manage spillover effects. Irrigation feeds directly into river basin management, being the dominant water user. The sector is reviewed separately in view of the special focus on water user groups and participation. Anti-poverty programs through light on how benefits can reach those sections of the population that may be marginalized even by local governments. Finally, delivery of infrastructure services is relevant to river basins in view of issues relating to economies of scale, regulation, and how costs can be recovered. Lessons about aspects such as financing and management capabilities may be gathered from all these sectors.

\section{Education}

Rules set out in the constitution, or instituted through legislation, and regulations, define the framework within which the education system works. The principle of subsidiarity is about changing the rules so that decisions can be taken where the action in question is located, provided the ability to take responsibility for the decision-outcomes exists (McGinn and Welsh, 1999 and Davies and Hentschke, 1994). Organizations at lower levels that can take decisions related to education include the field offices within the education ministry, state government, parent-teacher association, school administration, board or council, and the municipal government.

\section{Objectives for decentralization in education}

Decentralization in education is undertaken for reasons similar to those in other sectors. Specifically, to relieve the financial burden of central governments, to increase efficiency in providing educational services by allowing lower level organizations to take decisions. Efficiency and effectiveness are enhanced when decisions are made based on local requirements and available resources. Further, by transferring day-to-day and other administrative tasks to lower levels expensive delays may be avoided making service provision more cost effective and timely. Lastly, decentralization is desired to have an inclusive policy so that the preferences of hitherto disadvantaged sections of society are also considered.

Although everyone is affected by education in one form or the other, stakeholders are generally those who receive education and their parents, those who provide any inputs such as books, buildings and other materials for the educational process to take place, teachers, their training institutions, 
principals and others who are directly involved in running the school system, those who employ the skills that education provides to generate profit, and finally political parties and taxpayers.

The response of stakeholders to decentralization depends on what the specific objectives and policies are and how they benefit from it. For example, publishers of text books may prefer more centralized choice of course materials in order to take advantage of economies of scale in their production. Where access to even primary education is limited parents, students, and potential employers support decentralization policies that focus on more expanded coverage of primary education. Employers seeking highly skilled workers may prefer to endorse more high quality training at the expense of greater coverage, given limited funding. Taxpayers and political parties simply want to see public funds being used more efficiently and would support decentralization policies for that reason.

\section{Functions and decisions}

The functions and associated decisions in the education sector may be broadly classified as (1) establishing basic norms such as minimum schooling requirements and structure of the system, (2) curriculum and teaching methods, (3) evaluation, examinations and supervision, (4) teacher training, staff salaries, transfers and assignment, (5) sources and budgeting of recurrent expenditure, and (6) capital expenditure for construction of buildings and facilities (Ahmad, 1992).

Education systems range along a continuum of mostly centrally controlled to largely decentralized arrangements with a wide range of combinations of centralized and decentralized responsibilities in between. Of these functions, school organization is almost always under central control. Other functions may be carried out locally but under centrally specified norms. For example, examinations may be designed centrally but administered and assessed through field offices. Alternatively, the appointments of teachers chosen by local school boards may be approved by the ministry of education.

In more decentralized systems, functions other than those pertaining to school organization are taken up at local levels in a variety of ways. Primary and secondary education is controlled by state or municipal governments in Mexico and Colombia. In Australia, elected councils are responsible for primary education. Chile relies on charter schools while private schools are encouraged in Pakistan in recent years (Malpica Faustor, 1994; Ahmad, 1992). In current practice, central finance plays a prominent role in most countries. Further, education has to compete with other sectors for regional or state government contributions. For example, these may be matching funds for school construction or revenue budgeted for recurrent expenditure.

\section{Centralization and decentralization in the education sector}

The past century saw the formation of many national governments especially in developing countries emerging from colonialism and the strengthening of existing ones around the world. The nature of these political transformations was such that strong centralized control of most sectors, including education, seemed the logical step to organizing necessary services and to put administrative structures into place as quickly as possible. The guiding principle was efficient management in a manner that achieved as much coverage as possible with existing resources.

In education, this reasoning translated to standardizing curricula and procedures so as to extend the facility to as many as possible. Standardization allowed economies of scale in the production of inputs and guaranteed a relatively uniform, high quality product. This became manifest as similar course materials, standards and conduct of examinations, and teacher qualifications. Besides, the simultaneous growth of urban centers also promoted scale economies. Countries that centrally controlled education had more students enrolled and good quality education when compared to others. Theories of what helped to enhance the learning process could be uniformly applied by a system where the decision was taken by the ministry of education. However, central governments were neither able to expand coverage fast enough nor maintain good quality to satisfy demand from growing populations. For example, the large demand for education that goes unmet and the poor attendance of teachers in rural areas is viewed as a failure of the centralized system (PROBE, 1999).

Standardization is now viewed as the main drawback in the education system because it dissuades local managers from using local information to modify the rules to reach targets more efficiently and to enable smooth functioning of the institutions. McGinn and Welsh, (1999) suggest that 
decentralization in education means "groups of social actors attempting to control education to serve their unique objectives." Technological advances in communication, especially the internet, now present new possibilities to revitalize the education sector.

A central debate in education is whether an elected body accountable to the community is qualified to take responsibility or do decision-makers have to be education professionals knowledgeable about the sector? The underlying assumption is that there are some "best practices", known to education professionals, which guarantee services at acceptable levels, when implemented. The decentralization argument is that if local non-experts are somehow trained to take some of the decisions that experts can take then the political process will yield the same results. For example, Govinda (1999) describes the Lok Jumbish project in India, where women and other previously marginalized village members were brought into the process of decision-making and established a new political decision-making process for education. Further, if high standards have to be met to survive then local decisionmakers will take appropriate steps irrespective of whether they are education experts or not. The pressure may come from market forces as with private schools or from central supervision and evaluation that demands that performance meet some minimum criteria, as for example, with publicly funded private schools.

In systems where professional experts manage education, authority is usually deconcentrated from the ministry of education to representative offices at the state or district level. In Argentina, there are ministries of education in each of its 24 provinces. Otherwise the system may depend on schoolbased management, as in Los Angeles, USA (McGinn and Welsh, 1999). Here, the principal has ultimate responsibility which may or may not be shared with teachers. The success of this strategy depends on incentives to perform, the ability of those involved and the quality of supervision. The community participates in this system through parent teacher organizations and is generally concerned with fund-raising activities for school projects, such as, building facilities and supplies of materials including computers. Decisions about the curriculum and staff related matters are retained by the professionals. McGinn and Welsh (1999) argue that in homogeneous societies with a high degree of training, there would be a convergence between control by professionals and political appointees.

School councils or boards, composed of principal, teachers, parents and sometimes students exist in many countries, such as Australia, Nicaragua, and New Zealand. Although the distribution of authority between schools and councils differs across countries, the central idea is community control through elected council members with sufficient autonomy for schools. The composition of the council or board determines the degree of control by professionals. Similarly, the political composition of the council could have equity implications especially if one group dominates all others.

Champions of free market forces suggest that elected officials only reflect the majority view even if election procedures were fair while proposals by professional experts do not cater to everyone's needs as would market competition. Under a free market system, on the other hand, only those schools offering the most desired programs would be funded and thrive while others would be driven out by lack of demand for them.

Schools in a free market system may be private or public. The main feature in this system is that consumers may choose from a range of options available to them. The range in question may exist in the form of a variety of curriculum offerings, quality of teachers and instructional materials within the public school system itself. Alternatively, private groups or cooperatives may be contracted to run schools using public subsidies. This is the case with charter schools in New Zealand and Chile (Perris, 1998; McGinn and Welsh, 1999). The schools control their budget and also staffing and may or may not decide on the curriculum, although they do need to achieve specified educational standards. Communities in some African countries (Mali, Burkina Faso) have set up schools in villages by designing their own curriculum and using local teachers with the help of nongovernmental organizations (DeStefano, 1996)

Private schools contribute to primary and secondary education in many countries, as for example, in India and Pakistan. In this form of decentralization private schools may be privately funded and 
completely autonomous or publicly subsidized but privately run, as in Belgium, with or without funding through fees (McGinn and Welsh, 1999). The purpose is to offer schooling to all sections of society even if the strategy is sometimes inefficient, as with schools in remote areas. There is little scope for community participation in schools that are privately owned and the focus of management is usually to maximize revenue.

Key requirements for successful decentralization in the education sector

For successful decentralization it is a key requirement for local authorities to be capable decisionmakers. It is a different skill from being able to effectively carry out decisions handed down from above. In practice, central governments retain control of curricula and criteria for award of degrees in order to maintain uniform standards. This may mean that the qualifications and training necessary for teachers are also centrally determined because teachers have to impart the knowledge contained in the chosen curricula. Decentralization in education, on the other hand, implies diversity by definition. Decisions relating to choice of teaching materials, conducting tests and examinations, guidelines for instructions, time-tables, maintenance of building facilities, and sometimes even curriculum may be taken at lower levels rather than by central authorities, who are too remote to be aware of the needs in the sphere of activity. Similarly, decisions concerning the fundamental rules, such as, what accomplishments qualify for a degree, student-teacher ratio, and number of school days in the year are also suited to local consideration.

Other decisions including those related to class sizes and criteria for admissions are dependent on finances. Although these decisions may be made locally, financial sources and budgeting may or may not be determined locally. As with health, both central and state contributions are used for education and must compete with other sectors for fiscal support. Private schools depend largely on user fees and are financially unaffordable for middle and lower income groups resulting in disparities in the quality of education imparted, as has been observed in Pakistan (Ahmad, 1992).

If the goals are greater coverage, suitability of skills to potential, particularly local employers, and efficiency, then encouraging local management is essential. Local managers, including school administrators, must be taught how to select curricula so that the authority to set curricula, and other related decisions involving training local teachers and selecting text books may all be transferred to them.

In the education sector, one strong source of resistance is from teachers. Teachers oppose authority to appoint and fire staff being vested in non-professionals because they fear political interference and corruption. Similar concerns about corruption are expressed with respect to setting of pay scales and promotions. Besides, it is practical to assign the authority to transfer teachers to those who have an overview of the distribution in the nation or state or district as the case may be.

Another concern is that of sustaining interest in discharging the new managerial and decision-making duties in addition to those normally associated with instruction. For example, in systems based on school-based management, teachers find decision-making responsibilities too burdensome and allow principals to exercise all the authority. This is reinforced by the fact that principals may be held accountable for performance. Hanson, (1995) cites instances in Spain where teachers are not enthusiastic about being elected as principals for the above stated reasons.

\section{Healthcare}

As in education the pattern of health system organization is linked to the kind of government and political ideology that exists at the centre and decentralization is espoused for a variety of reasons. For example, decentralization in the health system in Mexico and in Papua New Guinea came about because the goals of decentralization are a matter of national policy in all sectors. In Mexico, a country with a federal structure, decentralization originated in a need to balance power among the center, states and municipal governments (Gutierrez in Mills et al, 1993). In Papua New Guinea, a country whose population is widely dispersed over several offshore islands and with over 500 languages, decentralization was a way to enhance interaction between the government and its citizens (Reilly in Mills et al, 1993). 
Hanson et al. (1997) emphasize the importance of context to trigger and guide reform. In a study of 8 African country experiences in the health sector, they find the health sector had reached a point of breakdown in all the countries studied. Benin's public health centers faced an acute shortage of drugs between 1983 and 1985 and Lusaka, in Zambia, witnessed cases of cholera between1990 and 1991. Under these conditions, reformers began to test pilot projects on a small-scale with local and external assistance. However, it was changes in the larger political context that provided opportunities for health sector reform on a large scale. New governments were eager to be perceived as harbingers of positive change especially in depressed health sectors. At the same time health sector reforms could be debated and discussed drawing on the experience of the small-scale experiments and guided in new directions. The arrival of a new health minister in Guinea encouraged heightened debate and progress with reforms. The changes embarked upon received further credibility due to the BI declaration ${ }^{4}$ at the World Health Organization Regional Health Ministers' meeting on decentralized health systems in 1987. Strengthening of weak local structures, making local government responsible and accountable to its constituents, and at a practical level, to improve the management of logistics, coverage and quality of service are the expectations from this approach.

\section{Objectives for decentralization in healthcare}

Improving coordination, increasing local control, and cutting costs are the three most important strategies of decentralization in the health sector. Primary health care may be maximized within a defined geographical area, especially if it is one that coincides with an administrative area, such as a district (referred to geographic decentralization). This is to ensure intrasectoral coordination among various aspects of health ranging from family health and nutrition, to mother and child care and disease control. Coordination may also be achieved with complimentary services in other sectors, such as, maintenance of social hygiene in terms of clean water, sanitation and waste disposal. Further, coordination must occur among governmental and nongovernmental organizations and private providers.

Improvement in the quality and quantity of health care is to materialize through local control of day-to-day activities, including decisions concerning staff, facilities, community financing, and resource allocation, particularly with respect to primary health care. Local control is organized through a variety of bodies, including independent hospital administrations, advisory councils, and separate boards and directorates for specialized care, such as, preventive health, disability, and environmental health.

Cost cutting may come from organizing the health system to minimize service duplication, especially with respect to those services provided by secondary and tertiary health care facilities so that they are more uniformly distributed to cater to the health needs of demarcated areas. Local management is expected to increase efficiency by utilizing scarce resources to address locally specific health concerns. Some of the financial resources are to be released by tailoring central staff requirements to emphasize planning, regulatory and technical advisory functions and reducing the number assigned to administrative duties. With greater community control, some local financing could also be raised.

Paradoxically, unlike in the education sector, where standardization calls for more central control, decentralization is seen as a way to urge more equality and uniformity among regions and between rural and urban areas in the provision and standard of health care services. In many instances, health sector reform leading to a decentralized structure has actually unified previously disparate parts in the process. In Chile, The National Health Service of the 1950s was a state run organization, geographically decentralized for administrative purposes (Montoya-Aguilar and

4 The Bamako Initiative (BI) refers to an endorsement by African Ministers of Health at the World Health Organization (WHO) Regional Meeting in Bamako, Mali in 1987. 
Vaughan in Mills et al., 1990). This organization covered health care for blue collar workers and unemployed people, and along with another agency called The National Medical Service for Employees became the National Health Fund in 1979. About this time decentralization began to take shape as private provision of health care was being encouraged to relieve the state of some of its financial burden. Since then, the health system has evolved so that there are four levels of management with distinct functions.

\section{Functions and decisions}

The main functions of the health sector encompass policymaking, planning and legislation, allocation of financial and other resources to programs, management of health sector activities including personnel matters, budgeting, procurement of medicines, equipment and other supplies, hygiene and maintenance, billing and scheduling. Other responsibilities include staff training, disseminating information about programs, such as, family planning, rehabilitation of drug and alcohol users etc. Most notably, the functions are intra (as among different health services) and inter sectoral (as among health, water and sanitation, education, transport, and welfare programs) coordination. In addition, regulation and integration of the activities of nongovernmental sectors and private providers so that they meet the standard of service are equally important.

\section{Centralization and decentralization in the healthcare sector}

Nations are not similar in the mix of centralized and decentralization functions they adopt in the organization of their health system but the following paragraph briefly summarizes general observations. In many countries, legislation, planning, and regulatory functions remain in central control. In more devolved systems, as in Mexico, Spain, and Papua New Guinea, governments at lower levels (state or provincial departments) may have the authority to perform these functions, but with central supervision. The most decentralized functions are those that reduce the financial burden on the central government and those that relieve central office staff from decisions concerning the day-to-day activities relating to service provision, particularly where local staff is more aware of the circumstances and also to avoid unnecessary delay in responses. These functions are management, intersectoral and intrasectoral coordination, and organizing community participation.

The extent to which other functions, such as, budgeting and allocation of resources, staff training, local planning and fund-raising are carried out is determined by the form of and degree to which decentralization has advanced. For example: in Zambia, day-to-day management of responsibilities is delegated to the semiautonomous Central Board of Health, from the Ministry of Health. Other functions are deconcentrated as the Ministry of Health administers health care through its district level offices and local health boards Bossert et al (2000). The system allows local control to a limited extent. Some items such as expenditures, fees, and contracting can be decided upon at the district level but others relating to staffing and salaries are not within their purview. Coordination from the perspective of a national health plan remains centralized. In a deconcentrated approach, the ministry of health is usually involved in negotiating with the central government, social security and health insurance organizations and in allocating resources to lower levels, especially with respect to large capital investments like major hospitals or medical research institutes. Sometimes the allocation of resources may be delegated to a separate agency, as with the National Health Fund in Chile.

The planning function itself can be mostly autonomous or deconcentrated to a small extent. The local government may devise a strategy for all public services that it is responsible for and design programs for implementation in the health sector on that basis. On the other hand, local planning may be done within central guidelines with approval sought for some or all of the projects. A deconcentrated version is to simply implement a central plan or get central approval for desired projects. In India, Chile, Mexico, and the U.S.A. plans and decisions on capital projects at lower levels are formulated based on central or regional guidelines and the finances available. Planning and budgeting are usually decentralized to the same extent so that sufficient financial support for programs is assured.

When faced with the question of what level to decentralize to, policymakers have to balance four conditions (Mills et al, 1990). The number of levels should be within a conceivable budget, so that available financial resources are not overstretched. Some services, like hospitals with specialized 
services, are viable only if there is a large enough jurisdiction for potentially sufficient demand. On the other hand, the number of levels has to be large enough that decentralization is close to the grass roots level for community participation. But too many levels could go beyond the supervisory capacities of higher levels.

In order to accommodate these considerations, the lowest administrative level, typically the district is chosen to which authority is decentralized and supported by a number of councils, health committees and other bodies to promote community participation. Alternatively, the local power structure itself consists of a number of government bodies that represent the interests from the grassroots level upwards. The district level, however, is too small to support a hospital with specialized services. So, the next higher administrative level, the region or province, is selected to situate hospitals with more advanced care to cater to referrals from all the districts below it. The regional level is found to be the most viable because of the high level of management expertise and timely assistance from other sectors that are necessary to operate the hospitals. In this instance, the regional level is stronger than the district level, to which authority is generally deconcentrated rather than devolved.

An important question is about who is represented on the governing bodies as this determines the degree to which decisions are influenced by the community and to what extent the members may be held accountable. If authority is devolved to the local government then the decision makers are elected officials. If authority is deconcentrated to local health committees as in Chile, or to hospital management boards as in Sri Lanka, then members may represent providers like charitable or nongovernmental organizations, prominent citizens, activists, health professionals, or local government officials. Their contribution could range from being purely advisory, to planning, and even fundraising. These governing bodies strengthen the mechanism at the district level by debating issues of local interest as inputs to planning and management and assisting in coordinating health care activities at that level. If the members are all elected then they would be accountable to the voters otherwise they are not.

One problem faced with community participation is that of capture of governing bodies by local elite as experienced in India and Papua New Guinea. In Senegal, for example, opposing political interests at the center are sometimes replicated in health committees. The effect of this depends on whether the dominant voices are those in support of the political party at the center or against it (NDiaye in Mills et al., 1990).

\section{Implementation issues in the health sector}

The process of decentralization begins when the principle of decentralization has been formally adopted by the national government through edicts or decrees. Subsequent to this step, the ministry of health generally undertakes the task of identifying functions that can be devolved or deconcentrated to lower levels, within the framework where the government has authority. If some health services, such as, family planning activities, are to be privatized or delegated to private providers, then the central government will have to legislate to integrate their role into the decentralization scheme. Making the changes will mean investing in new health care centers, teaching hospitals, and institutes for medical research, in order to provide the necessary tools in regions and districts. As this stage reaches a critical mass, the national health system emerges as the rules, roles and responsibilities are assigned and boards, councils, and committees are established to promote coordination and realization of the objectives. All this takes time, skills, and resources.

Hanson et al. (1997) describe health sector decentralization in West and Central Africa as "incremental, non-linear and long-term". In Zambia, steps in fiscal decentralization and founding of new institutions were taken faster than those relating to drug programs. An interesting observation is that there is a phase during which both the old and new systems co-exist. In Mali, workers felt more secure to be employed by government paid health centers rather than those funded by the community, resulting in difficulties in hiring workers for the latter. Experience in many countries points to the following major obstacles that local governments are faced with when decentralizing the health sector: 
(1) While devolution of power fulfills a key demand of decentralization, successful implementation is compromised by inadequate financial resources. Even if the local government has the authority to raise revenue, their tax base is usually insufficient to support health and other programs. The potential for increased revenue from property, land, entertainment tax, and licensing is limited. Local government, therefore, has to depend on financial transfers from the center, whose revenue comes from sales tax, customs, and excise duties.

(2) Local governments are not completely independent from central control because of their financial dependence on central funds. If these are in the form of block grants they are not earmarked for any purpose. Alternatively, they may be transfers targeted to specific programs, as with projects to control malaria, in India. From the national perspective allocation methods could be used to promote critical programs, like family planning, or to control the spread of a communicable disease like SARS in China. Further, central allocation may be used to reduce regional differences in the level of health care. Unfortunately, regions or states with political interests that are aligned with the center may receive preferential treatment through the allocation procedure. However, in many decentralized systems both central and state contributions are divided among local governments usually taking the population base into account. How much of its collection the local government may keep is a much debated issue.

Financial inadequacy is a hurdle even in Chile where health sector decentralization is relatively advanced. Gideon (2001) describes the experience of a center in the low-income neighborhood of El Bosque. The municipality has refused to contribute financial resources and expensive equipment remains unused due to lack of recurring supplies. The new system of fiscal decentralization is based on a per capita system of funding. However, due to insufficient information especially about the actual number of beneficiaries, many municipalities underestimate the total cost and the amount budgeted by the Ministry of Health for the purpose falls far short of actual expenses. The municipality is expected to fill the gap but health has to compete with other sectors for resources. As may be expected, the problem is exacerbated in poorer neighborhoods, like El Bosque, than in more well to do ones, introducing disparity in the quality of services at family health centers. Oddly enough, a system that was set up specifically to reduce inequalities among municipalities is unfortunately failing to do so because administrative decentralization has taken place in isolation without fiscal and political decentralization to support it.

Bossert et al (2000) stress the necessity to include household incomes in the formula for transparent allocation of grants to districts. In Zambia, where district level services are financed through a combination of grants and collection of fees, allocation of grants to districts is based on population but not household income levels. So, although the poorer districts did receive larger grants they could not raise sufficient income from fees thereby causing disparity among district level services.

In developing countries, uncertainty of adequate finances for long term capital projects, at lower levels is a particularly serious problem. In Senegal, for example, the community (through the health committee) may spend $50 \%$ of its revenue on drugs and capital investments but it is restricted from raising funds for operational costs. Currently they manage with external aid (NDiaye in Mills et al., 1990).

Another major hurdle experienced by many countries is the acute shortage of skills. The dearth of planning skills required for reorganizing the health sector so that programs can be carried out at the lower levels is experienced at the ministry of health itself. Staff at the lower levels has to be prepared, willing, and able to accept authority. In addition to management and administrative skills, some knowledge of planning and programming is also necessary if decentralization involves devolution. For example, the study on Zambia (Bossert et al, 2000) notes those guidelines for expenditures relating to personnel allowance, drugs, fuel, and capital were efficiently implemented at the district level, but not in contracting for hospital services which requires more experience. In the early stages, considerable technical help and support has to be provided by the ministry of health. In Congo and Senegal, program managers from the center provided an important source of experienced staff for training activities (Hanson et al., 1997). 
Opposition from entrenched staff has to be overcome. Instead, staff commitment to the goals of decentralization must be won through training for any progress to occur. The civil service, for example, sees their independence and authority eroded by the empowerment of local groups as has been recorded in Sri Lanka (Rondinelli, 1983). Similarly, the concerns of those who believe they are adversely affected by the changes due to decentralization must be addressed. In eight African countries studied by Hanson et al. (1997) authorities had to persuade private pharmacies that their urban market base was not being shrunk by the decentralized health centers, whose top priority was efficient programs for the procurement of essential drugs.

Decentralization affects the relationship of health workers with the community. While training and better services enhance their standing in the community, it comes at a cost in terms of a greatly increased workload, most often with no salary improvements. On the other hand, health workers view their influence over patients as being eroded by community management. In Congo, refusal by doctors to accept treatment protocols supervised by heath committees was overcome by having them design the protocols themselves. In this way they could continue to be respected by their patients as the authorities on medical care.

Long-term commitment to voluntary (unpaid) work as members of health committees is uncertain as has been observed in Benin and Guinea (Hanson et al., 1997). While the health sector deals with other questions, such as, how to provide health care to those who cannot afford to pay for the services, the above obstacles are identified as the major issues in decentralization.

\section{Gains from decentralization}

Thus far, studies have reported gains ranging from (1) a large increase in the number of health units and hospital beds, (2) more coverage, in terms of primary health care and medicines, for the uninsured and unemployed, (3) building construction, renovations, and extensions, (4) standardization of salaries for health workers (Mexico). Others, such as the study on Zambia, Bossert et al (2000) suggest that there have been no significant improvements attributable to decentralization although maintaining health utilization rates for health services in spite of general economic decline and increase in HIV/AIDS, may be credited to the reforms.

\section{Roads}

Decentralization in the road sector is more complicated than in other infrastructure sectors because (1) roads are useful only as part of a network and not on their own, (2) there is little control over the level of traffic including pedestrians, or the total load that impacts it (Robinson and Stiedl (2001). According to Humplick and Moini-Araghi (1996a), there are two factors that influence service delivery: (1) technical characteristics and (2) diversity of demand which reflects the different expectations that users have of what roads should do for them. Further, construction involves large lump sum investments for inputs, machinery and equipment, therefore, this function benefits from economies of scale. If construction activities are localized then we see more contracting out to the private sector (Lopez-de-Silanes et al, 1995 provides evidence of this in the US). Even in this case, procurement skills and supervision are required and the center is considered better equipped for these activities. But maintenance is labor-intensive and periodic so decentralization might be preferable in this function. This point, however, is refuted by Robinson and Steidel (2001) in the context of rural roads because of the keen management skills required.

\section{Objectives for decentralization in the road sector}

Decentralization is expected to prevent decision-making bottlenecks experienced under central control by increasing understanding of local conditions and relieving central departments of routine operational duties and decisions so that they can focus on planning and policy work. More control at the local level, allowing diverse views to be represented, may lead to more innovative solutions to problems and result in expansion of the area covered by the service.

\section{Functions and decisions}

Important tasks constituting delivery of road infrastructure are construction, rehabilitation, maintenance, and administration. The corresponding functions for providers are planning, selection, and management. Administration of roads refers to decisions about where to make investments, 
how to procure works and monitoring quality of construction and maintenance. Cost minimization is a key concern in this sector.

The roles and responsibilities in the road sector may be summarized as follows (Madelin and Parkman, 1999; Robinson and Stiedl, 2001): The role of owner, generally, ministry of transport or works, consists of setting road policy, establishing the legal and regulatory framework for management of road networks, and for funding the programs. The administrator, a road authority or agency, ensures that the road policy is being carried out as envisioned. Often the administrator's duties are clubbed with those of the manager, who actually plans the activities, supervises, and monitors the operations. This function can be contracted out to private consultants. Contractors carry out the operations. Contracts can involve public or private sector and are specific to particular tasks. Alternatively, responsibility may be assigned within the public sector so that an agency can carry out tasks within an agreed upon framework.

\section{Centralization and decentralization in the road sector}

Decentralization is possible in the road sector broadly along the following lines: In a deconcentrated model the central government is the owner and administrator otherwise these roles are devolved to the local government (e.g. district). In either model, the role of the administrator may be delegated to the private sector. The central government and local government may enter into agency arrangements with each other or the local government as owner may appoint a committee of local members to act as administrator for it. The manager and contractor's roles can be undertaken by the private sector or performed by a department within the administrator's office (Robinson and Stiedl, 2001).

In two studies, Humplick and Moini-Araghi (1996a, 1996b) throw light on which functions are more cost-efficient under decentralization. They define resource costs as those related to provision (cost of inputs to production, management and administration) and preference costs as those related to the perceptions of and impact on road users. When conditions are bad then the cost to users is high and the demand is low and vice versa. Resource costs are identified with efficiency objectives and preference costs with equity considerations. Based on a comparison of eight countries, they conclude that decentralization increases costs at first due to loss of scale economies and later becomes more efficient when roadwork is more in local control, although there are costs to collective decision-making. Decentralization, functional and fiscal, is examined in construction, maintenance, and administration by comparing resource and preference costs.

In construction, the best approach is to take advantage of economies of scale, which the authors argue, is either through complete decentralization or complete centralization. Resource cost efficiency will depend on degree of competition among bidders and not to level of decentralization. Preference costs are lowest when decentralization is complete, that is, users receive what they want.

In theory, decentralization is good for maintenance activities (relative to construction) because locals choose their preferences and success depends on accountability, and local involvement. But even here the results are mixed. Maintenance of roads is most efficient under complete decentralization when both functional and fiscal decisions are decentralized (as in Indonesia and USA). However, if financing, procurement and management are centrally determined and implementation of maintenance is functionally decentralized, then incentives to minimize costs are not high at the local level. The authors cite the example of Germany, where minimizing preference costs appears to have a higher priority than minimizing resource costs in road maintenance, perhaps so that all areas have uniformly good road conditions. Utilization of the centrally allotted earmarked funds is not efficient with respect to provision of maintenance although preference costs are low.

Another determining factor for efficient road maintenance is adequate local skill levels. Colombia has performed poorly despite functional decentralization and earmarked funds. When local skills are insufficient, maintenance activities are awarded to private contractors. Under this scenario, efficiency 
gains in maintenance are more dependent on enough competition in bidding procedures than in whether it is being done at the central or local levels, especially if administered by the center. Lack of competition $^{5}$ is a concern at the local level more than at the center. On the other hand, the link between public expenditure and road maintenance is less clear to local citizens under fiscal decentralization than when they make choices themselves, even when using earmarked funds.

Central governments have a key role in administration especially in regulating safety and network externalities and maintain their control through partial funding of administration. In administrative decentralization (measured as the fiscal share of local government in administrative works), preference costs are lowest when providers can be held accountable to users but this is difficult because there are costs to ensure users are well informed. In Korea decentralized administration lowered preference costs showing that local involvement in decision-making about road expenditures improves road conditions.

The conclusion is that ultimately which functions are best decentralized depends on the structure of allocation of fiscal and functional authority. In poorer countries central governments should produce, plan, and budget, and manage hiring of labor and machinery. This is especially the case with construction.

\section{Problems in decentralizing the road sector}

The problems faced by the rural road sector suggest the reasons limiting improvement in roads, by transferring authority to the local levels. Hurdles specific to road administration include (1) not being able to attract international consultants for district projects because of their small-scale; (2) having to depend on labor-only contracts for maintenance, technology for which is not always supported locally; (3) lack of special skills needed for network-based planning; (4) recognizing the importance of maintenance to keep costs low; (5) being able to match available options, including low cost methods to spot repair roads and to choose road standards, appropriate to the use they will be put to, in order to keep overall costs down (Robinson and Stiedl, 2001).

In field studies of Uganda, Nepal, and Zambia, Robinson and Stiedl (2001) report a lack of accountability mechanisms between central and local governments and between local governments and the communities. Monitoring of activities by the private sector is usually carried out by central authorities and there are no avenues for users to signal their assessment. Neither is the use of funds transparent.

Not enough authority is transferred to the district level so that local decision-makers can be flexible with the limited resources available. For example, if they want to demand maintenance instead of new roads. Insufficient political clout with the center is a problem especially when there is still a lot of dependence on the center for planning, funds and technical support.

Another problem is that contracting for district projects with international consultants is difficult because they are small-scale. Attempts to expand the size of the project by including other districts, takes away local control, as for example in Zambia. In Uganda, district officials do not feel involved because small-scale maintenance projects are carried out on the basis of labor-only contracts administered locally.

Decentralization seems to give authority to locals who lack the management skills necessary for maintenance of rural roads. Except for involvement by engineers in external projects, there are few opportunities for training to enhance the limited capacity leaving local governments leaning on technical support from the center. Skills, needed to manage new construction and development, are quite different from those needed for maintenance. In Nepal, district committees are unsure about how to implement the Road Master Plan.

5 When implementing projects under the decentralized set up in Kerala, India, although the services of contractors were sought only as a last resort, to avoid corruption, in reality many beneficiary committees had contractors or their nominees as the conveners (Sharma, 2003). 
Zambia is the only case where there is legislation in place that recognizes the importance of maintenance to retain road standards. In Nepal, however, there is a tendency not to budget for the maintenance of roads that can rein in costs, and to focus instead on construction and repairs which are more expensive. Sometimes roads are built where they are not economically worthwhile. Also, the standard of the road is unnecessarily high. For example, some of the main roads are of lower standard than that of the tributary roads that feed into them. Overall planning does not appear to contemplate less expensive options such as spot repairs to provide access within the limited budget reflecting poor planning.

\section{Results from decentralization in the road sector}

Brazil, Philippines and Indonesia are all centralized with respect to road construction and maintenance. Argentina, Colombia and Germany are more decentralized. United States is most decentralized in this sector. Brazil's per unit costs of provision are lower than in other countries due to restructuring of the construction sector yet roads are in poor condition in the provinces and municipalities due to lack of financial and skill resources to assume new roles (Humplick and MoiniAraghi, 1996).

Robinson and Stiedl (2001) report that decentralization of roads administration is not effective in improving rural road access for the poor because they are not involved in planning, financing, and implementation and there is no way to know what they need. Few opportunities for employment are generated by construction and maintenance in the road sector at the district level.

The authors recommend devolved and delegated models where the road networks are large enough to take advantage of economies of scale; or bottom-up principal agency with the local government owner having an agency agreement with the center; and the establishment of a system for allocating funds for district roads as a share of a central Road Fund as existed in Zambia. With the road fund approach, however, local governments lose control over allotting expenditures. Capacity building and reliable source of funds even through user fees are other significant prerequisites to reap benefits from decentralization.

\section{Irrigation sector}

Current trends around the world suggest that governments lack the financial and other resources to supply and maintain irrigation infrastructure, water delivery, and extension services to irrigators. But irrigated agriculture is considered essential for food security in the coming decades. The agricultural sector, particularly irrigation, is the largest consumer of water, a finite natural resource for which multiple users compete. For all these reasons it has become imperative that agricultural productivity levels are maintained or increased through sustainable irrigated agriculture within the financial capabilities of governments, and most importantly, to ensure that water is efficiently allocated and used.

In pursuit of these objectives, decentralization is taking place in irrigation through the transfer of management responsibilities to farmer groups or Water User Associations (WUAs) in several countries. WUAs maintain on-farm small irrigated canals, allocate water among their members, collect revenues, and represent farmers' interests to the irrigation authority. They also serve to resolve conflicts that arise from complaints by farmers, especially with respect to allocation issues (Hamdy, 2002).

When discussing the impacts of irrigation management transfer, Vermillion (1997) cites studies in the Philippines, Indonesia, Mexico, and Sri Lanka, which report a fall in government expenditure for operation and maintenance. The savings are potentially available to defray infrastructure construction and rehabilitation costs. A large part of the savings to the government comes from staff reduction in irrigation agencies with allocative functions being taken over by the WUAs. Further, governments aim at recovering at least the operation and maintenance costs, and in some instances, a part of the capital costs, of supplying water. Sometimes farmers also contribute labor to maintenance activities.

WUAs support themselves through income from irrigation fees, membership fees, revenue from the supply of goods and services such as, contract machinery hire, fines, interest, and 
donations. Transfer programs can claim to be quite successful in cost recovery. Comparison of collection rates between government run schemes and the Irrigation Associations (IAs) in Turkey illustrates this point. In reimbursable irrigation schemes managed by the State Hydraulic Works (DSI), investment costs and $\mathrm{O} \& \mathrm{M}$ expenditures cannot be charged for recovery until ten years after project completion. The $\mathrm{O} \& \mathrm{M}$ costs of the previous year are charged the following year without being adjusted for inflation (although the inflation rate is around $70 \%$ ). Collection rates between 1985 and 1998 ranged from 32\% to 50\% while the penalty for farmers who do not pay on time is only $10 \%$ per year. On the other hand, user organizations, the IAs, have been more successful with fee collection. After transfers, the rates for a sample of IAs averaged about 85.6\% between 1994 and 1998 (Cakmak, 2002; Yazar 2002).

\section{Problems faced by Water User Associations in irrigation management}

Financial inadequacy is experienced by water user associations when it comes to "lumpy" services such as equipment maintenance, or to purchase the equipment themselves. This situation arises when they lack a legal basis (as with the IAs in Turkey) and policy for joint purchases or cost sharing for rehabilitation.

An important issue is the opacity of management of cooperatives. In the Red River Delta in Vietnam, farmer cooperatives balance their budgets but provide no details to farmers to justify the costs (Fontenelle and Molle, 2002). Farmers are, therefore, reluctant to pay for irrigation and drainage costs. Despite a fee collection rate of $92 \%$ by the cooperatives, the Irrigation and Drainage Management Companies, which depend on the cooperatives for their income, show cumulated deficits and unbalanced budgets. Fontenelle and Molle's study suggests that financial losses result from a lack of transparency and detailed accounting. Issues of accountability are also observed by Yazar (2002) in the Lower Seyhan Irrigation Project in Turkey. The new role of the state irrigation agency, DSI, is unclear and there is danger that the monitoring, regulation, policy and finance, and the support services that are expected from it may be abandoned.

Facon (2002) focuses on the link between irrigation infrastructure and management practices. It is important for WUAs to improve water delivery through system operation strategies that are consistent with the flexibility that farmers need. In addition to infrastructure and distribution rules, managerial skills have to be upgraded. Functions involve a lot of record keeping, responding to delivery requests, monitoring water availability and allocation, financial assets, and equipment and maintenance programs. The ability to use tools for modern information and management systems will also called upon. The "bir Ben Kemla" water user association in Tunisia's Sahel (Lebdi, Hamdane and Lamaddalena, 2002) has successfully applied water storage techniques to allow discharge-based rotational delivery to manage water by volume.

Quassem (2002) surmizes that sustainability of water institutions needs a guarantee of funds for operation and management activities and training and skills for stakeholders as well as incentives for staff of the government agencies, whose support is essential.

Unver and Gupta, (2002) point to the poor representation by farmers and water users in the irrigation associations in Turkey, specifically, the presence of village and municipal heads, elected to serve purposes other than the interests of farmers. In practice, the irrigation associations function like agencies of the government that can legally recover their costs from users and are not based on participatory management. Further, there is no incentive to make long-term investments because they lack a legal claim to assets they generate.

Resistance to decentralization in the irrigation sector comes largely from staff attrition in irrigation departments and agencies. Yazar (2002) notes that one reason for government expenditures, in Turkey's Lower Seyhan Irrigation Project, still remaining high is because staff levels have not declined fast enough. Vermillion (1997) however, cites among others, studies in Philippines (Oorthuizen and Kloezen, 1995) and Mexico (Johnson, 1996) reporting a reduction in agency staff due to transfer programs. 


\section{Issues in public infrastructure services}

The broad functions of decentralization in infrastructure sectors, such as electricity are planning and program design, financing, coordination of various institutions, providing technical assistance, tariff and other regulation, selection of appropriate technology, allocation of benefits, project operation, management, and maintenance, cost recovery and evaluation of performance.

The case of rural electrification in Chile illustrates how successful decentralization may be implemented in an infrastructure sector (Jadresic, 2000). Policymakers recognize that involvement by the private sector is essential in rural electrification. However, low consumption and high costs of distribution to users scattered in remote locations combine to make the service unattractive to private providers. Thus, the strategy aims to find efficient solutions by incorporating government at all levels into a scheme to generate market incentives for private investors or to find alternative technologies for very isolated communities. Thus the main objectives are to promote private investment, encourage competition taking into account the structural reforms in the industry, and to fit the selected method into the decentralization program of the national government.

The success of this program lies in the way in which it attempts to overcome the problems that afflict decentralization in general. The strategy is (1) to take local preferences and conditions into account; (2) to ensure financial adequacy through joint financing; (3) to lay down clear rules that encourage transparency in selection of projects and so that the roles at various levels are apparent enough to inform consumers about who is accountable for what; (4) to make certain of local involvement with a focus on sustainability; and (5) to be flexible to accommodate alternative low cost solutions in the future.

The central government, through the National Energy Commission (CNE) plans and defines the policy, partially finances, provides technical assistance, and coordinates the institutions involved in the program. The $\mathrm{CNE}$ also sets the criteria for evaluation and establishes the rules for deciding among competing projects to ensure transparency. The regional governments identify electricity needs, choose solutions, and participate in decisions on the allocation of investment funds. Upon the request of the community and the municipality, the distribution-company or private consulting company prepares a project proposal. A regional agency evaluates the proposal based on criteria including the cost-benefit ratio, proportion of the investment to be made by the distributioncompany, and social return. The head of the regional government presents the selected proposals for funding by the regional council.

Financing is done on a joint basis, with users being responsible for tariffs and the in-house costs of wiring, metering, and grid connection. Capital investment and management costs are covered through contribution by the distribution company and government subsidies. Both central and regional governments contribute to the program through a special fund and allocation depends on progress in the previous year and the number of households without access to electricity.

The program is flexible enough to respond to technological advances if they prove to be economically efficient. Alternative self-generation technologies, such as photovoltaics and small hydroelectric power stations are also considered for remote communities in the hope that future demand increase may make it worthwhile to switch to linking to the main grid. As a result, distribution companies have an incentive in staking out their territory in advance, since they do not already hold exclusive rights.

The program has been successful both in terms of coverage and increasing private investment. Coverage increased from about $50 \%$ to over $75 \%$ of rural households between 1992 and 1999 . The state's contribution has been steadily declining while private investment continues to grow. Aware that they are accountable, regional governments see the success of the program as politically sensitive. 


\section{EQUITY, CAPTURE BY LOCAL ELITE, AND LESSONS FOR INFRASTRUCTURE DELIVERY}

Unlike infrastructure delivery programs, where the beneficiary pays for service delivery in one form or other, the poor in antipoverty programs are too poor to pay in any form. The experience with respect to devolution of responsibility to local administrators, to identify socially disadvantaged groups informs us about the nature of allocation decisions taken at the local level. This literature is important because proponents of decentralization assume smoothly functioning democratic systems and the existence of necessary institutions at local levels, which is not the case in developing countries. Equity issues in several case studies, for example, Koppel (1987) on the Bicol River Basin, Philippines and Ioris (2001) on the sub-middle section of the São Francisco River Basin, Brazil suggest the relevance of questions about corruption at the local level to successful decentralization in integrated river basin management.

Concern has been expressed in the decentralization literature that the expected gain in efficiency from better local information, may be compromised due to more corruption at the local level relative to the national level. When the authority to target communities for public services and for targeted programs is devolved to local governments then it is particularly important that the local government is not captured by local elite. If captured, services may or may not reach the targeted beneficiaries. Besides, there is less accountability due to a breakdown in the democratic process. (Mathew and Nayak, 1996).

Evidence in the literature on local capture is mixed. Galasso and Ravallion (2000), in a food-foreducation program in Bangladesh, find that communities with larger land inequalities did not fare well in reaching the poor. However, those villages that had cooperatives for farmers and the landless were better in identifying the poor. These results seem to suggest some evidence for capture but the presence of local institutions influenced targeting performance in a positive way. They also note that the program improved in terms of becoming more pro-poor as it advanced. Alderman (1998) finds that the social assistance program in Albania appears to be relying on local information and is relatively well targeted to the poor compared to similar programs in other low income countries. The study does not find any indication of usurping of benefits by local elite.

Bardhan and Mookherjee (1999) make the point that institutional structure for local accountability is not already in place in developing countries and unless the local power structures are changed by some means, infrastructure delivery can be diverted to local elite who capture the government. In this respect, the central government has an important role in setting up structures that encourage participation by the disadvantaged in policy discussion and decision-making and also in choosing methods for fiscal decentralization that limit the scope for capture by local elite.

The authors demonstrate, through their analytical model based on voting behavior, that susceptibility to capture by vested interests need not necessarily be greater at the local rather than at the national level. Where the likelihood of capture is greater depends on the specific context, which in turn can be analyzed using voting patterns and other data inputs. This suggests that expected efficiency gains from decentralization need not necessarily be negated by a lack of accountability due to manipulation by local elites. The extent of capture depends on how factors, such as, voter awareness (inversely proportional to inequality), predictability of the election outcome, and electoral competition, play out at the local and national levels. Fisman and Gatti (2000) contradict these findings with evidence suggesting that larger federal transfers are associated with higher rates of conviction for abuse of public office in the United States.

Bardhan and Mookherjee (2001) study how the volume of infrastructure service delivery, including roads, water, electricity and telecommunications, is affected and whether local elite (rather than others) are more likely to be the beneficiaries of decentralization under different financing mechanisms. They find an overall increase in the volume of service delivery when local governments enjoy more fiscal autonomy. But local elite enjoy a disproportionate share of the benefits relative to others. The extent to which this inequitable distribution occurs depends on how much power is 
devolved to the local government to raise funds locally and to what degree this power is captured by local elite.

The financing mechanisms examined are local taxes, user fees, and central grants. When fiscal autonomy is greatest, as it is if local governments can levy and bear the cost of collecting taxes, the extent of local capture will determine whether decentralization has succeeded in improving service delivery compared to central control. The extent of capture is however less relevant when user fees are collected because payment is contingent upon service delivery and the user is free to be the judge of that. For this reason decentralization based on charging user fees, wherever feasible, combines the advantages of flexibility in responding to local needs with greater devolved authority and can be more efficient than centralized bureaucracies. (This does not however rule out overprovision to elite altogether as that would depend on factors such as the location of the services.)

A key result of the analysis is that if revenue decentralization is not devolved to local governments along with authority over expenditure choices then the volume of service delivery is adjusted downward whether the local government is accountable (that is capture) or not. Financing through central grants does not devolve fiscal authority to local governments and is therefore less efficient compared to charging user fees. With central grants, if the funds are insufficient to provide service to everyone then either provision favors elites depending on extent of capture by them or with a severe financing constraint both elites and others suffer from a lack of infrastructure services. Central grants may be qualified as unrestricted, tied to expenditures, or matched to particular services. Again, their success with respect to service delivery will depend on how much flexibility they allow to respond to local needs and if at the same time they cannot be easily allocated elsewhere. In practice, a combination of financing mechanisms is used (Dillinger, 1995).

\section{DECENTRALIZATION DESIGN: SELECT ISSUES FOR INTEGRATED RIVER BASIN MANAGEMENT}

The promise of decentralization in the context of river basin management is an exciting one and could contribute significantly to improved efficiency in water use, greater equity in allocation of water, and the preservation of delicate ecosystems. However, in practice, effective decentralization is not easy.

This section identifies criteria to gauge success of decentralization based on case studies of river basin management in Latin America, Sub-Saharan Africa, and Asia. These case studies have been chosen because recent analyses provide reasonably detailed accounts of river basin management and decentralization in a wide variety of developing country contexts. Highlights of the case studies and

their sources are presented in table 2. The observed success criteria are then discussed in conjunction with the lessons gathered in the review of other sectors.

\section{Experience with decentralization in river basins}

A useful starting point, for the discussion on river basins, is the summary assessment by Walmsley and Hasnip (1997a) of the reasons for success achieved by the Murray-Darling Basin Commission in Australia. These authors recognize that the technical skills, funding, and governance available in the context of the Murray-Darling Basin may not be feasible for most developing countries. Yet, they argue that the lessons learned from that experience could provide relevant pointers and benchmarks. The authors apply their criteria for success to developing country river basins in China, Ethiopia, India, and Zimbabwe and find them useful as a framework for evaluation (Walmsley and Hasnip 
1997b). The case studies below confirm the importance of the considerations that Walmsley and Hasnip (1997a) lay out ${ }^{6}$ :

Political will to ensure a "workable and agreeable framework" turns out to be critical because important decisions are continually needed to make progress while maintaining the trust of stakeholders.

Administrative and financial autonomy for an "apex" organization that integrates basin-wide activities.

An open information policy to establish inter-disciplinary communication and hence improve assessment methods and decision support tools.

A strong and enforceable legal base, for example, to allocate property rights, place limitations on ground water extraction, and establish a water pricing and cost recovery policy.

Community awareness, community inputs for formulation of strategy and plans, and community-led programs to achieve appropriate and sustainable outcomes.

To guide the discussion in the rest of this section, the criteria outlined above have been adapted in table 2, which presents a simple framework and also a summary description of the case study examples. The choice of criteria in this paper is guided by the focus on the goal of achieving accountability and in particular, the historical and political factors that are conducive to the realization of that goal. The columns in this table list the key factors that influence successful decentralization. The set of initial conditions shapes the seriousness with which decentralization objectives can be pursued; the political leadership displayed in implementing decentralization is key to building the necessary trust and ensuring that difficult decisions are legitimized; and the technical arrangements that generate accountability include effective subsidiarity, transparency of objectives and responsibilities, and the allocation of property rights.

First, it appears that among initial conditions the physical characteristics of the area, such as the extent of aridity, are not necessarily consequential. This may be so either because greater political commitment is generated in areas that are economically important and or because they have strong institutions. Political commitment is critical to establishing effective property rights, which is central to playing the coordinating function when centralized structures give way to decentralized decisionmaking.

Second, implementing the principle of subsidiarity is essential if decentralization is to achieve successful management outcomes. The case studies highlight the fact that governments have moved towards decentralized functioning and they have also initiated the creation of necessary institutions; but, so far, the principle of subsidiarity has remained mainly an objective. In the progressive cases, such as those in Latin America and South Africa, there is a greater commitment to translating the principle into practice. But in other cases, such as, in the Philippines, Nigeria, and China, the evidence suggests that administrative devolution and subsidiarity are not working. The details of the case studies suggest several factors such as clear definition of roles and rules, capacity and access to information, and, most importantly, effective mechanisms for conflict resolution are vital for subsidiarity to flourish.

Third, integrated river basin management faces significant hurdles when there is no transparency, especially in terms of correspondence between stated goals and actual programs. For example, in the Bicol case study, although the stated goal is area development by integrating multiple objectives, in reality the focus is only on increased rice cultivation. In addition, although beneficiary participation is a key element of the strategy, there is little evidence of involving all stakeholders. Transparency and efficient communication of information become especially important in the context of decentralization. They are essential to the effective participation of stakeholders.

${ }^{6}$ For a similar discussion, see also Visscher, Bury, Gould, and Moriarty (1999). These authors study integrated water resources management principles in the context of drinking water supply and sanitation projects. 
Table 2: Factors contributing to successful decentralization

\begin{tabular}{|c|c|c|c|c|c|}
\hline $\begin{array}{l}\text { River Basins/ } \\
\text { Countries/ } \\
\text { Sources }\end{array}$ & $\begin{array}{l}\text { Location and } \\
\text { Initial } \\
\text { Conditions }\end{array}$ & $\begin{array}{l}\text { Political } \\
\text { Leadership }\end{array}$ & $\begin{array}{l}\text { Decentralization } \\
\text { and subsidiarity }\end{array}$ & Transparency & Property rights \\
\hline $\begin{array}{l}\text { Curu, Jaguaribe, } \\
\text { and } \\
\text { Metropolitana } \\
\text { /Ceara,Brazil/ } \\
\text { Kemper and } \\
\text { Olson (2000) }\end{array}$ & $\begin{array}{l}\text { Semi-arid; } \\
\text { largely surface } \\
\text { water; } \\
\text { recurrent } \\
\text { droughts; poor, } \\
\text { largely } \\
\text { agricultural }\end{array}$ & $\begin{array}{l}\text { National } \\
\text { commitment; } \\
\text { positive State } \\
\text { initiative }\end{array}$ & $\begin{array}{l}\text { Water management } \\
\text { company } \\
\text { (COGERH) to } \\
\text { implement at basin } \\
\text { level; water storage } \\
\text { system under user } \\
\text { management }\end{array}$ & $\begin{array}{l}\text { Clear } \\
\text { objectives; } \\
\text { sound legal } \\
\text { framework; user } \\
\text { registration } \\
\text { under way }\end{array}$ & $\begin{array}{l}\text { Ceara's law does } \\
\text { not permit water } \\
\text { rights, because } \\
\text { rights not } \\
\text { tradable; some } \\
\text { careful testing of } \\
\text { water rights } \\
\text { concept }\end{array}$ \\
\hline $\begin{array}{l}\text { Yellow } \\
\text { River/China/ } \\
\text { Zusman (1998) }\end{array}$ & $\begin{array}{l}\text { North China; } \\
\text { faces water } \\
\text { shortage; } \\
\text { droughts, } \\
\text { sediment }\end{array}$ & $\begin{array}{l}\text { Declared } \\
\text { national policy } \\
\text { to ensure water } \\
\text { supply, mitigate } \\
\text { water pollution }\end{array}$ & $\begin{array}{l}\text { Basin level } \\
\text { commission } \\
\text { (YRCC); limited } \\
\text { participation by } \\
\text { stakeholders; } \\
\text { implementation } \\
\text { basically top-down }\end{array}$ & $\begin{array}{l}\text { Process } \\
\text { characterized by } \\
\text { ambiguity and } \\
\text { discretion }\end{array}$ & $\begin{array}{lr}\text { All } & \text { water } \\
\text { belongs } & \text { to } \\
\text { Chinese } & \text { state } \\
\text { according } & \text { to } \\
\text { constitution } & \end{array}$ \\
\hline $\begin{array}{l}\text { Lerma- Chapala } \\
\text { /Guanajuato, } \\
\text { Mexico/ } \\
\text { Reynoso (2000); } \\
\text { Merrey } \\
(2000)\end{array}$ & $\begin{array}{l}\text { Semi-arid to } \\
\text { arid; serious } \\
\text { water crisis, } \\
\text { groundwater } \\
\text { overexploited; } \\
\text { economically } \\
\text { developed, } \\
\text { agriculture, } \\
\text { industry }\end{array}$ & $\begin{array}{l}\text { Keen national } \\
\text { commitment; } \\
\text { positive State } \\
\text { initiative }\end{array}$ & $\begin{array}{l}\text { State managers of } \\
\text { National Water } \\
\text { Commission } \\
\text { (CNA); Basin } \\
\text { Councils (COTAS); } \\
\text { authority also to } \\
\text { other State, } \\
\text { municipal, and user } \\
\text { level entities by } \\
\text { function; }\end{array}$ & $\begin{array}{l}\text { Participation of } \\
\text { users in } \\
\text { regulation and } \\
\text { enforcement; } \\
\text { established } \\
\text { feedback } \\
\text { mechanisms; } \\
\text { use of financial } \\
\text { incentives }\end{array}$ & $\begin{array}{l}\text { Law mandates } \\
\text { implementation } \\
\text { of system of } \\
\text { water rights, } \\
\text { including } \\
\text { discharge } \\
\text { permits; aim to } \\
\text { establish water } \\
\text { markets }\end{array}$ \\
\hline
\end{tabular}

\begin{tabular}{|c|c|c|c|c|c|}
\hline $\begin{array}{l}\text { River Basins/ } \\
\text { Countries/ } \\
\text { Sources }\end{array}$ & $\begin{array}{l}\text { Location and } \\
\text { Initial } \\
\text { Conditions }\end{array}$ & $\begin{array}{l}\text { Political } \\
\text { Leadership }\end{array}$ & $\begin{array}{l}\text { Decentralization } \\
\text { and subsidiarity }\end{array}$ & Transparency & Property rights \\
\hline $\begin{array}{l}\text { São Francisco } \\
\text { (sub-middle } \\
\text { basin) } \\
\text { /Brazil/ } \\
\text { Ioris (2001) }\end{array}$ & $\begin{array}{l}\text { Variable semi- } \\
\text { arid climate; } \\
\text { water scarce; } \\
\text { degraded } \\
\text { environment; } \\
\text { poor area with } \\
\text { powerful } \\
\text { landowners; } \\
\text { strategic area, } \\
\text { supplies } \\
\text { hydropower } \\
\text { downstream }\end{array}$ & $\begin{array}{l}\text { National } \\
\text { commitment to } \\
\text { IRBM; Federal } \\
\text { control not } \\
\text { coordinated }\end{array}$ & $\begin{array}{l}\text { Semi autonomous } \\
\text { Federal agency } \\
\text { (CODEVASF); no } \\
\text { central committee } \\
\text { overseeing basin; } \\
\text { decisions } \\
\text { influenced by } \\
\text { powerful } \\
\text { landowners; } \\
\text { landless laborers, } \\
\text { sharecroppers } \\
\text { voiceless }\end{array}$ & $\begin{array}{l}\text { Lack } \\
\text { transparency in } \\
\text { impact } \\
\text { assessment of } \\
\text { dams is among } \\
\text { key issues }\end{array}$ & $\begin{array}{l}\text { Allocation of } \\
\text { water permits } \\
\text { not easy since } \\
\text { many users not } \\
\text { documented }\end{array}$ \\
\hline $\begin{array}{l}\text { Bicol/Philippi- } \\
\text { nes, S.E. Luzon } \\
\text { island/ } \\
\text { Koppel (1987) }\end{array}$ & $\begin{array}{l}\text { Floods, } \\
\text { typhoons; lacks } \\
\text { basic } \\
\text { infrastructure, }\end{array}$ & $\begin{array}{l}\text { Government } \\
\text { leadership not } \\
\text { manifest; user } \\
\text { groups losing }\end{array}$ & $\begin{array}{lr}\text { Basin } & \text { level } \\
\text { committee } & \\
\text { (BRBCC) } & \text { under } \\
\text { Cabinet supervision }\end{array}$ & $\begin{array}{l}\text { Complex } \\
\text { management } \\
\text { resulting in } \\
\text { mistrust, }\end{array}$ & $\begin{array}{l}\text { Centralized } \\
\text { control; } \\
\text { beneficiary rights } \\
\text { not likely in the }\end{array}$ \\
\hline
\end{tabular}




\begin{tabular}{|c|c|c|c|c|c|}
\hline & $\begin{array}{l}\text { among poorest } \\
\text { regions in } \\
\text { country }\end{array}$ & interest & & $\begin{array}{l}\text { evidence of lack } \\
\text { of transparency }\end{array}$ & near future \\
\hline $\begin{array}{l}\text { Olifants/South } \\
\text { Africa/ } \\
\text { Merrey (2000) }\end{array}$ & $\begin{array}{l}\text { Sub-Saharan } \\
\text { arid; acute } \\
\text { water scarcity, } \\
\text { pollution from } \\
\text { mines; few } \\
\text { basic services, } \\
\text { infrastructure; } \\
\text { very poor } \\
\text { region }\end{array}$ & $\begin{array}{l}\text { National } \\
\text { commitment, } \\
\text { focus on equity; } \\
\text { only some } \\
\text { stakeholders } \\
\text { aware and } \\
\text { organized }\end{array}$ & $\begin{array}{l}\text { Basin level agencies } \\
\text { (CMA); intent to } \\
\text { encourage user } \\
\text { participation exists } \\
\text { but process slow }\end{array}$ & $\begin{array}{l}\text { Policy of } \\
\text { transferring } \\
\text { ownership and } \\
\text { management of } \\
\text { small-scale } \\
\text { irrigation } \\
\text { schemes to } \\
\text { users for } \\
\text { transparency }\end{array}$ & $\begin{array}{l}\text { Government } \\
\text { responsible for } \\
\text { water resources } \\
\text { management as } \\
\text { public trustee, } \\
\text { provides for } \\
\text { licensing water } \\
\text { uses }\end{array}$ \\
\hline $\begin{array}{l}\text { Cross/Nigeria/ } \\
\text { Udofia (1988) }\end{array}$ & $\begin{array}{l}\text { Sufficient } \\
\text { quantity of } \\
\text { surface water } \\
\text { available; yet } \\
\text { water } \\
\text { provision } \\
\text { major problem; } \\
\text { poor } \\
\text { management }\end{array}$ & $\begin{array}{l}\text { Declared } \\
\text { national } \\
\text { commitment to } \\
\text { rural } \\
\text { transformation } \\
\text { via river basin } \\
\text { strategy; not } \\
\text { backed up by } \\
\text { careful planning }\end{array}$ & $\begin{array}{l}\text { River Basin } \\
\text { Development } \\
\text { Authorities (RBAs); } \\
\text { subsidiarity } \\
\text { ineffective, largely } \\
\text { central control }\end{array}$ & $\begin{array}{l}\text { Government } \\
\text { actions did not } \\
\text { comply with set } \\
\text { priorities; no } \\
\text { financial } \\
\text { support } \\
\text { provided for } \\
\text { development } \\
\text { program }\end{array}$ & $\begin{array}{l}\text { Government in } \\
\text { charge of water } \\
\text { resources } \\
\text { management }\end{array}$ \\
\hline
\end{tabular}

\section{Latin American case studies}

Management of the Lerma-Chapala River Basin in Guanajuato State, Mexico. The Lerma-Chapala River Basin is frequently cited in current literature as a promising example of decentralized management (Kemper and Olson, 2000; Merrey, 2000; Mestre, 1997; Reynoso, 2000). Based on all accounts, the transition from a decidedly centralized system to a participatory management structure has been rapid and has already initiated several programs focusing on water allocation, water quality improvement, wastewater treatment, efficient water use, and monitoring the level and quality of water in Lake Chapala to name a few.

The Lerma-Chapala basin is shared by five states. The basin covers about 77 percent of the state of Guanajuato located in central Mexico. It is this area that is highlighted in this case summary. About 85 percent of the water is used for agriculture, 12 percent as potable water, 12 percent for industry, and 3 percent for trade and services.

Three features of this area are of particular significance. They are: (1) Guanajuato state ranks sixth out of 31 states in its contribution to the national gross domestic product; (2) the hydraulicgeography of Mexico is such that the economically advanced areas of the country, among which Guanajuato state is one, are in the semi-arid to arid zone; (3) groundwater is extracted at a rate that is greater than the rate of recharge resulting in serious over exploitation. Merrey (2000) estimates that 109 percent of available water is developed and used making it a "closed" basin because water depletion exceeds water supply. Increasing levels of pollution due to population growth and industrial expansion have exacerbated the situation.

Taking advantage of the "new Federalism" policy of the government, the National Water Commission (CNA) adopted a policy of decentralization to the state level in response to the insufficient coverage and inadequate finance in the sector. The regional representatives of the CNA, who are independent of the center, are responsible for regulation, coordination, and supervision of water sector activities. The Basin Councils advise the CNA's regional managers of the planning strategy. The National Water Law, which was approved in 1992, allows state governments to collaborate directly with river basin councils to finance and implement various programs in their water agenda. The state government could also now convey its plan to improve services in the water sector to the Basin Councils, through its regulating body, the State Water Commission. Thus, the 
key role of the River Basin Council is one of coordination and planning based on the information it receives through this feedback mechanism.

Within this new legal framework, the state of Guanajuato initiated its own strategy of promoting conditions for an integrated approach to sustainable development, with coordination among authorities and stakeholders. The State Commission for Water and Sanitation in Guanajuato (CEASG) was appointed to implement its policy and a State Council represents the water users in the state who participate in decision making through the Water Technical Boards (COTAS). Transparency, accountability, and trust fostered through visible commitment by the authorities are key factors for their strengthening and long term viability. The five-year financial trust set up by the state to support these organizations reflects a genuine interest in their survival. Users are also expected to involve themselves in some measuring and operating tasks. The media has been used extensively in Guanajuato to make the public aware of its program.

To sum up, in the new management structure, the federal government maintains its authority over Mexican water policy and performs its regulation and standardization functions but depends on the basin councils to coordinate and resolve conflict among all stakeholders, including representatives from all the states sharing the basin, and users. The state regulating body focuses on planning, capacity building, setting up financial mechanisms, efficient water management, and organizes user participation. In this manner, the state maintains a subsidiarity relationship with the center and users are expected to engage in a similar subsidiarity relationship with the state. The basin council in its turn is a feedback mechanism between the state, users and the CNA.

The factors that have enabled a successful transition to the new framework are: the initial conditions of water scarcity and the urgent need for a solution; the significant economic contribution of the area to the nation; and the acknowledgement of the inability of the CNA to improve conditions on its own; the presence of timely leadership at the center, articulated through legislation; the initiative taken by the state government to advance its own agenda in keeping with the new framework; the commitment to encourage user participation; and the clear mechanisms set in place to obtain feedback from all stakeholders.

Some potential weaknesses of the system pertain to accountability mechanisms to users, and the possibility of rent-seeking, favoritism, and nepotism that could threaten the existence of the irrigation associations (Kloezen, 1999, as cited in Merrey, 2000). Also, it is doubtful if all the voiceless poor are also included in the dialogue. Others while acknowledging success in reducing water allocated to irrigation, point out that the level of Lake Chapala is still continuing to reduce (Wester, Melville and Osorio, 2000, as cited in Merrey, (2000).

Integrated River Basin Management in Brazil. In 1989, the Brazilian Water Resources Association recognized "the watershed as the territorial unit for management purposes," in the Declaration of Foz do Iguacu. Following this, in 1991, the state of São Paulo issued the State Law on Water Resources Management System, in which it launched, for the first time in Brazil, a bulk water charging system, and decentralized water management through River Basin Committees, Porto (1998). Ceara state also adopted the river basin approach in 1992. Several other states including Bahia and Pernambuco continued the pattern in 1996 and 1997 respectively. Finally, the Federal government legitimized the process of decentralization through the National Water Resources Management Act, the final version of which was signed in 1997 . It is noteworthy that several interested stakeholders were consulted over many years to reach a consensus for the final text of the Act, Porto (1998).

The National Water Policy, defined by the Act is based on the Dublin Statement (1992). It adheres to the principles that water is a public good and a finite resource with an economic value and must be managed for multiple purposes, through a participatory approach involving government, users and citizens. It expressly recognizes the watershed as the territorial unit for management.

The new management system relies on an institutional structure involving River Basin Committees and their executing arms, the Water Agencies, at the basin level, and other agencies at the federal, state, and municipal levels with a specific assignment of functions to each institution according to their respective capacities. 
Following are three case studies of river basin management in Brazil, two of which are relatively successful in reorganizing the sector and grappling with inefficient water use and one case that has failed to make much headway despite being governed by the same new law as described above. The cases are the river basins in Ceara state, the Piracicaba river watershed in São Paulo state, and the portion of the São Francisco river basin that lies in the states of Bahia and Pernambuco.

The Curu, Jaguaribe, and Metropolitana Basins in Ceara State, Brazil. Ceara state, like Guanajuato in Mexico, is another example that has reformed its water sector. Three river basin committees manage its river basins under the state's own reformed water management system and the umbrella of the country's new water law. For a detailed case study, see Kemper and Olson (2000) on which this summary is based.

The Ceara is situated in the semi-arid Northeast of Brazil. Its area is roughly 148,817 square kilometers and the population is about 7 million. The area has very little groundwater and receives an annual precipitation of 600 to 800 millimeters interspersed by droughts. Due to the irregularity in rainfall, the predominant method of securing adequate water supply has been through the construction of several thousand reservoirs where surface water is stored and delivered. About 45 percent of total water is used for irrigation.

Water policy reforms in Ceara began with the preparation of the state water resources plan by the Secretariat of Water Resources, in 1986. Based on this, the state water law was passed in 1992, which established the legal background to management at the river basin level. The World Bank played an active role in guiding the reforms whose objectives included charging tariffs for all users, establishing water user associations, testing the concept of a water market, and the founding of a new water resources management company, Companhia de Gestao dos Recursos Hidricos (COGERH). Since 1994, COGERH has set up three river basin committees, namely, the Jaguaribe, the Curu and the Metropolitana basins. Among other positive outcomes are the launching of several water user committees at the river basin level, the introduction of bulk water pricing structures for industries, irrigation and for the state sanitation company, and instituting professionally managed supply systems. The process of decentralization was enabled by about 400 sponsored events that brought together participants from irrigation and industry. The introduction of a water market, however, proved to be too ambitious, given that the existing law does not allow it.

The present conditions have evolved gradually by combining the different motivating factors of various state agencies. For example, COGERH took three years to gain control of the reservoirs, whose management it now shares with another agency. Finding the Curu and Jaguaribe basins unable to pay tariffs that could cover operation and maintenance costs, COGERH sought to reduce water usage through collective decision making in water user committees. So far, it has succeeded in doing so in the Curu basin.

The Piracicaba River Basin. Porto, (1998) provides an example located in São Paolo state. Here, the Piracacaba River Basin Committee manages three river basins. This is a highly developed area with conflicting demands for water from industry, households, agriculture, and consumers in the Metropolitan Region of São Paulo. Although the mean precipitation is 1400 millimeters, water shortage is still felt. The problem of sewage treatment is also in need of immediate attention.

The seeds of collective decision-making were sown when the mayors of all the municipalities in the basin resolved to improve water quality. In 1991, the State Water Resources Management System invested the River Basin Committee with the authority to prioritize the steps to be taken. The 48-member group represented equally by the state government, stakeholders, and municipalities determined to upgrade both water quality and quantity aspects, with public participation; charge for bulk water; sort through conflicts and agree on how state and other funds were to support the process.

Except for charging for bulk water, all other objectives are proceeding with satisfactory progress. By 1997, four wastewater treatment facilities were restored. US\$10million is earmarked for more projects, including a new water resources information system.

The Sub-Middle Section of the São Francisco River basin. The São Francisco River flows in the interior of Northeast Brazil. The sub-middle section of this river covers approximately 390,000 square 
kilometers in the Bahia and Pernambuco states. It has a tropical semi-arid, variable climate that may change from a few months of intense precipitation to long dry spells. The mean annual precipitation is 350-600 millimeters and droughts occur from time to time. About three-fourths of the water is consumed for irrigation, which, apart from production, is viewed as a means to control drought. Hydropower generation is the other major user.

Three notable features of this area are: (1) it is strategically situated because it provides hydropower to downstream cities; (2) it is a federal river because it crosses interstate boundaries; and (3) it is controlled by large landowners who influence the local economy including federal actions taken with respect to water allocation and control.

The Company for the Development of the São Francisco Valley (CODEVASF) is in charge of managing the water resources in the basin. While some effort has been made to encourage efficiency in rural areas, so far the main accomplishment has been to construct large irrigation projects with the help of federal investments described as "inefficient" (Simpson, 1999, as cited in Ioris, 2001) and has focused on emergency measures rather than taking steps towards risk management. Further, while the public sector is responsible for many of the investments, little has been done to maintain navigable waters and resolve the mismatch between power generation and oil driven irrigation schemes (Romano and Cadavid Garcia, 1999).

Ioris (2001) describes how a lack of continuity in implementing plans and the inability of federal, state, and municipal agencies to coordinate under a system of centralized decision making outside the basin, have contributed to disappointing results, despite the new integrated approach being fostered by the center. Among these results is the failure so far to deal effectively with the widespread environmental degradation, in particular, the highly polluted water contaminated by mines and industries in the upper reaches.

But one of the key reasons for failure to implement reform is the uneven social structure, with wealth concentrated in the hands of the landed few while the majority of the landless population lives on rain-fed agriculture. This section of the population, with no formal property rights survives on subsistence farming, carried out with the help of government subsidies in public irrigation districts. Consequently, expansion of public irrigation is slow and proves inadequate as a means to support the farmers in times of drought. The reason for this inaction is linked directly to the fact that water scarcity chiefly affects the deprived groups while those capable of coping with droughts are unwilling to break with the traditional ways of storing water in order to maintain their control (Livingstone and Assuncao, 1993; as cited in Ioris, 2001).

The other key reason for unsatisfactory management is the failure to settle conflicts in water allocation. There are several sources of dispute. Water is diverted for irrigation purposes upstream, while sufficient flow is required to operate the hydropower plants downstream. Similarly, flood control implies reduced flow at certain times, which clashes with the interests of hydroelectricity production and navigation, both of which need larger volumes of water. Other sore points include the privatization of the federal hydroelectricity utility and the proposal to transfer water to basins in the north of the river without open discussion. With respect to the latter, there is evidence of a lack of transparency and accountability especially since the negative impacts of the proposal have not been properly assessed. It is unclear if the displaced persons would receive any compensation, and there has been no justification for the enormous expense.

Comparison of the various cases presented in Brazil. Looking at the success stories and the last less progressive case, we may observe some important factors that led to the differing outcomes. All three cases are similar in one respect: in all cases improper management practices led to the decline in water services and to serious environmental degradation.

Ceara state showed political leadership by instituting their own reformed water law and by setting up a water management company to implement it. Taking note of the watershed as the territorial unit for water management, the mayors in the Piracicaba river basin embarked on a strategy of collective action, which later evolved into the constructive proposals adopted by the São Paolo state. In the São Francisco River Basin, however, most intervention still appears to be made by the federal government. Kemper and Olson (2000) note that, "under Brazilian law a state has full jurisdiction 
over a river that flows entirely within its own boundaries; otherwise the river is subject to federal legislation." Perhaps the fact that the São Francisco is a federally controlled river explains the lack of initiative at the local level. In fact, Ioris (2001) informs us that there is yet no central committee overseeing the whole basin.

From another angle, it is tempting to conclude that a relatively well-developed economy is conducive to implementing rapid reform. The idea that water is an economic good and its provision has to be paid for is likely to be easier to implement under these conditions. Certainly, the relatively developed initial conditions in the Lerma-Chapala basin in Guanajuato, Mexico and Piracicaba basin in Brazil may be presented as evidence.

In contrast, where the majority of the population scrapes together a living based on small scale farming, translating this idea into practice would be much more difficult, as is the case in the São Francisco sub-middle basin. This basin sub-division and those in Ceara are drought prone, struggle with a variable climate, and an uneven social structure. However, what explains the gains made in Ceara? It may be argued that the decentralization of decision making to the state level and the fact that the new government, in the state, was more industry and business oriented served to break from the traditional focus on large-scale irrigation alone. But in the São Francisco sub-basin, federal government intervention, the relative independence of the landowners, bureaucrats and engineering companies due in part to their influence with the federal agencies and the formal property rights of landowners, appear to have combined to thwart any progressive reform. Another observation that bolsters this view is that large amounts of financial resources have been budgeted for projects relating to river management, yet they are not seen to be helping to fulfill the stated objectives. For example, US\$ 750 million over 10 years has been allocated for various measures to cope with environmental degradation and the estimated cost of transferring water to basins further north is US $\$ 1.5$ billion (Ioris, 2001).

This brings the discussion to the issue of transparency, both in planning and financial expenditure, to foster trust in the government's actions. In the São Francisco case, the uncertainties and lack of answers to questions raised about the proposal to transfer water further north calls for a greater degree of transparency. This is also suggested by the fact that there is controversy surrounding what positive impacts the proposal would have for local stakeholders and that there is little public participation in preparing for negative fallout. Also, the discontinuity in implementation when governments change has resulted in a loss of confidence in the minds of the public who doubt the objectives articulated by the federal government are going to be fulfilled in their area.

Participation by various stakeholders is consciously incorporated into the implementation program in the river basins in Ceara and the Piracicaba basin. The result is that COGERH, in Ceara, was able to negotiate with stakeholders having conflicting incentives and arrive at a working arrangement for the present. The Piracicaba River Basin Committee is equally represented by state government, municipalities, and stakeholders. It is yet to be seen how this group will handle the question of bulk water pricing which is on their agenda.

Again, with the skewed social structure referred to earlier it is unclear if the existing models of decentralization being attempted in Latin America can be successful without first dealing with wider issues, such as land reform. One question that arises is what common incentive could cement water user associations in the case of landless laborers to ensure that their voice is heard?

\section{African case studies ${ }^{7}$}

The Olifants River Basin, South Africa. This case study centers on the part of the Olifants River Basin that is accessible to South Africa for development and use. The basin, which is about the size of the

\footnotetext{
${ }^{7}$ Rangeley, Thiam, Andersen, and Lyle (1994) discuss several African case studies but they deal principally with
} sharing of international river waters and the discussion is by now likely to be outdated. 
Lerma-Chapala in Mexico, faces severe water scarcity. The shortage of water arises for two main reasons: (1) most of the flow from tributaries into the river occurs below this section, after which the river crosses into Mozambique; (2) water is diverted to thermal power plants in the upper stretch of the river. Pollution from the mines further intensifies the paucity of clean water.

The government in the Republic of South Africa has laid out the water policy framework in its National Water Act (No.36 of 1998) and the Water Services Act (No.108 of 1997). The policy sets forth the following: "equity in access to water resources, benefits and services; sustainability; optimal beneficial use; redress of past racial and gender discrimination; participation by stakeholders in decision-making about water resources; 'representivity' to ensure consideration of all stakeholder needs, interests and values; 'subsidiarity' i.e., devolution of responsibility to the lowest appropriate level; integration of water resource management functions; alignment of water resources management with other related departments' functions, and transparency to foster cooperation and encourage stakeholder support for decisions" (Merrey, 2000).

The policy statement is a clear commitment from the government based on the Dublin Statement, 1992. Further, the unit for integrated water resources management is stipulated to be the 'catchment' as the river basin is called in South Africa.

According to the new administrative structure, the government, through the Department of Water Affairs and Forestry (DWAF) is in charge of the nation's water resources based on the National Water Act. It continues to grant licenses for water uses, ensures minimum flows in rivers, and represents the national interest with respect to international sharing of river water.

Other management functions at the basin level will be carried out by "Catchment Management Agencies" (CMAs). Further devolution of responsibility will occur by organizing "water user associations" to provide local water services. To implement this, the government proposes to transfer the management of already existing small-scale irrigation schemes to the users.

Apart from the DWAF and the proposed CMA, the stakeholders in this context are the commercial farmers, water supply companies, the mining and industrial sectors, thermal power plants, and the unorganized sector including the small-scale irrigation sector. All sectors except the last are well organized to voice their interests. The government strategy is to ensure water security to high-value uses, but at the same time remedy the injustices of the past apartheid regime.

The process of implementing the guidelines of the National Water Act is at the stage of preparing the proposal outlining the CMA's mandate and in bringing together water user associations. It is therefore too early to look for successful outcomes. However, progressive outcomes so far are: it has been recognized that water scarcity can worsen without immediate appropriate action; a choice of reforming the water policy to one based on decentralized management has been made and it is yet to be seen what kinds of difficulties will be faced in implementation.

Cross River Basin, Nigeria. In the early 1960s, Nigeria was set on a course towards rural development through better land use. By the early 1970s, the experiment resulted in a few successes and a string of failures. At the same time, the worsening water supply situation and fear of a food crisis, led the government to pursue a different approach. The linkages between management at the river basin level and social and economic development, with water as the integrating element were seen to present an alternative means to achieve their objectives. In 1977, the government launched eleven river basin development authorities whose mandate was to "achieve fullest possible use of all resources in the basin" (Salau, 1990). The approach aimed at integrating the interests of irrigation, navigation, hydroelectric power, reclamation of flood-prone areas, soil conservation, recreation, and afforestation.

The Cross River Basin Committee was created within the above framework. This case is included in the sample of river basin management experiences because it is an attempt at decentralization, and it is a valuable case study for lessons in the context of Africa. The extent of decentralization and the nature of integration are not as comprehensive as articulated in the South African case, but may be viewed as an attempt in that direction, under its own unique social and political conditions. 
Cross River and its tributaries are located in the south of the country where in spite of plenty of water-most of it surface water, and huge expenditure, water provision, especially for agriculture, is still a constraint.

Udofia (1988) doubts if the objectives stated in the river basin decree will ever be accomplished under the present conditions. In fact, the author points out that the document was not carefully thought through because some of the objectives are irrelevant to the Cross basin. For example, there are no lakes or lagoons in the State, so development of fisheries did not apply, nor is any part of the basin so badly submerged as to need reclamation. Similarly, some of the projects were poorly conceived. The impact of fish farming will have greater impact in fish deficient areas rather than in places where they are plentiful. The underlying reasons for poor planning are a lack of data, financial resources, capacity, and transparency. In addition, the overlap of jurisdictions of different river basin authorities leads to conflict.

Emphasis on the need for accurate information on the quality and quantity of water resources and about the population of consumers is echoed in other studies in the African context (Salau, 1990; Stoffberg, van Zyl and Middleton, 1994). Scudder (1989) cites the inadequacy of project appraisal techniques and scanty environmental and social impact evaluation of large-scale river basin projects, to suggest a lack of interest in accountability.

Although the Nigerian government set priorities to integrate aspects of water and land resources, in reality, understandably, provision of potable water and food security received top priority. Most attention was paid to construction of large dams to the neglect of soil conservation, navigation, pollution control, flood damage reduction and even resettlement of displaced people in dam projects (Mitchell, 1990).

River Basin Development Authorities are made responsible for many functions by decree; however, in practice they face resistance in states governed by political parties different from the party at the center. Their inability to coordinate proves to be an obstacle in trying to implement the government's agenda. Further, Scudder (1989) argues that in the context of dam projects, river basin authorities become "executing agencies for the coalition of developers....such other options as rain fed agriculture, flood water cultivation, and livestock management tend to be ignored, as is the participation of local organizations in the planning, implementation and evaluation of development projects and programs." It may be debated as to what kind of decentralized structure is the first best solution to achieve the government's stated goals.

\section{Asian case studies}

Yellow River Basin, China. "In 17 out of the past 25 summers the Yellow River's bed has been left dry further and further upstream for longer periods of time" (Zusman, 1998). A World Bank report concluded that water scarcity might have year round implications throughout northern China (World Bank, 1993b). Among principal factors contributing to water shortages are excessively sedimentladen flow, and increasing demand from different sectors, especially from agriculture. Zusman (1998) contends that the way in which the political system works with regard to water is the "factor most attributable to the current water problems."

The Chinese constitution stipulates that all water in the nation belongs to the Chinese state. The Chinese view of integrated management requires the development and utilization of water and disaster prevention to be planned in a comprehensive manner, with all relevant aspects taken into account, with full consideration of the multiple uses of water (Solanes, 1998).

The Yellow River Conservancy Commission (YRCC) was created in 1933 to coordinate conflicts between upstream and downstream users. Later, when political and economic reforms were introduced in the 1970s and 1980s, policymaking authority was devolved from the center to the provinces. A host of bureaucratic agencies from state, provincial and local levels are in charge of water resources in the Yellow River basin. Chief among them are the State Council, the Ministry of Water Resources (MWR), the YRCC, and the Ministry of Electric Power (MEP).

The MWR is in charge of basin level planning and must seek approval of its plans from the State Council. The nine provincial governments are equal in rank to the MWR and could influence 
decision making in keeping with their interests. The role of the YRCC is complicated since it is lower in rank than the provincial governments but is expected to coordinate the provincial needs in the basin with the plans of the MWR.

Zusman's (1998) view suggests an unclear definition of functions assigned to each agency. While there is a complicated structure in place, the processes and mechanisms by which the system is to operate are vague. Procedures such as the issue of water permits are informal and decided on a caseby-case basis. For example, which users can apply for a permit and which agency approves the permit are uncertain.

Another ambiguous factor is the role of the YRCC. Although it is responsible for coordination and planning in the basin, the agency finds itself limited in the extent of its authority. The existence of other smaller agencies in the upper and lower reaches of the river, which act relatively independently, undermines the YRCC's ability to serve as a unifying force needed to manage the basin as a whole. In addition, coordination between the YRCC and the government at the Center is lacking. To illustrate this Zusman (1998) refers to the long-discussed plan to divert water from the Yangtze River in southern China to the semi-arid/arid areas of the north, and in particular to Beijing. The opinion of water managers and the YRCC differs from that of the central government, which they contend is not based on conditions relating to the basin.

There is some interagency participation in the sense of bargaining to reach a consensus, but even here decision-making may be swayed in a direction favored by a more influential official such as a provincial governor.

In the opinion of Paterson (1986), "a key structural element inhibits integration and inter-agency cooperation.... A major barrier is the necessity for operating the public sector as a single unit for purposes of public policy, but as a collection of substantially independent units for the purpose of management" (Paterson, 1986 as cited in Mitchell, 1990). One consideration in setting up administrative structures is to define the function of each organizational unit as clearly as possible, although as Mitchell (1990) reminds us boundary problems will always occur. Integrated management of the Yellow River Basin serves to illustrate this point.

The Bicol River Basin, Pbilippines. The Bicol River is susceptible to tidal flooding and flooding after typhoons. Since the area does not have sufficient basic infrastructure it suffers from isolation when faced with natural hazards, especially after torrential rainfall. As a result, it is one of the poorest ranking regions in the Philippines with a per capita income that is 49 percent of the national average. Consequently, management of the river and flood control is linked to economic development of this predominantly agricultural region.

The Bicol River Basin Development Program (BRBDP) was decreed in 1976 with the "integration of national and local government programs and the decentralization of rural development project planning and implementation as the preferred development strategy for the Bicol River Basin" (Koppel, 1987).

The Bicol River Basin Coordinating Committee (BRBCC) was set up for policy making and coordinating functions at the program level. It began by creating task forces and working groups to forge links with regional offices of national agencies as well as provincial and municipal governments. However, it found its leadership role to be undermined because it was bypassed by the agencies it was trying to coordinate. A large part of the project development, implementation, and maintenance functions were carried out by local and national agencies in the region after direct negotiation with the center.

The development strategy was to target efforts in a single area with high growth potential, to create a growth pole for the whole region and to integrate planning across all sectors. Further, project planning and management was to be decentralized to maximize participation from all sectors in an area's development.

In reality the impacts were largely felt in only one province out of the six provinces in the region. The focus was almost entirely on rice production, which was expected to stimulate the rest of the economy. Out of 26,751 hectares targeted by the Program 10,600 hectares were irrigated, by 1985 . Irrigated area harvested increased by 29 percent between 1981 and 1984; total production in all 
irrigated areas increased by 36.8 percent, and yields in irrigated areas increased by 6 percent per hectare. At the same time, overall production in rain fed areas increased by only 1.1 percent and yields increased by 4 percent per hectare. Population grew by about 7 percent in the same period. The gains in rice production, however, did not lead to growth in the local economy, as the development strategy was expected to do. Rice productivity was helped by the newly constructed roads which opened up easier access to the markets in Manila, leaving the local warehousing, milling, and rice wholesaling businesses without the Program's benefits. Income distribution became more unequal between 1978 and 1983 in the entire region indicating that the Program did not influence the targeted province in any significantly different way. High rates of unemployment and underemployment continued and the region's per capita gross domestic product continued to remain among the lowest in the country.

Koppel (1987) reasons that although there were some positive outcomes the results may have been better if the last element in the strategy was actually followed, namely, decentralizing and maximizing participation from all stakeholders, including the beneficiaries themselves. By giving the local government more authority, especially in financial management and project administration, it would convey the idea that the local government is responsible for the maintenance of the project after it is complete, thus reducing transaction costs. In similar vein, if in this context, the farmers saw themselves as owners of the irrigation systems constructed for them, they would have the incentive to maintain them and further sustain the benefits that could accrue from the Program's investment. This could only happen if they were included even in the planning phase.

Koppel's argument essentially questions whether the funding and existence of a separate basin level agency, such as the BRBDPO in its current situation, can be justified given the experience so far. It can if it has a clearly defined basin-wide role with a special focus on building a broad base among stakeholders and beneficiaries. Instead it appears to have been like a supplementary government department that overlapped with existing mandates. There is plenty of evidence in Koppel's account to suggest that it was viewed by other agencies as an unnecessary competitor for authority, and financial resources. The underlying factor here is clearly one of a lack of political will at the center, which decentralized only in form but not by transferring any degree of authority or independence. In other words, there is no real principle of subsidiarity at work. This is important because decentralization based on subsidiarity, that allows local governments to recognize a body like the BRBDP as a basin wide institution with a unique and distinct mandate is the only way to find cooperation.

Neither did the BRBDP apply the principle with respect to the beneficiaries. For example, despite the various committees instituted to foster participation, only a select group, that excluded farmers, small business owners and landless laborers, was invited. Many members of the private sector were unaware of the Private Advisory Committee whose job it was to communicate between them and the BRBDP. There is evidence that farmers did try to participate but their role was limited to attending meetings where programs were described.

This example focuses on rural development through managing irrigation water, in the context of a river basin. It differs in some ways from the other examples in South Africa and Latin America where the issues are directly related to water allocation, pricing, or environmental degradation. However, the lessons learned are highly relevant to the implementation of integrated river basin management through a process of decentralization. As Castro (1995) explains, this process "...abruptly modifies a complex net of power relations built around water management. The reconstitution of this net of relations between the central power and the final consumer is a key issue within the current process of modernization."

\section{LESSONS LEARNED FROM OTHER SECTORS RELEVANT TO RIVER BASINS}

This paper identifies the set of initial conditions, the political leadership displayed in implementing decentralization, and the factors that minimize transactions costs, such as effective subsidiarity, 
transparency of objectives and responsibilities, and the allocation of property rights as key factors that influence successful decentralization in river basin management. Increased participation through water users associations and other mechanisms is crucial to successful decentralization and, potentially, has a high pay off. However, the prerequisites for effective participation are also demanding, especially where traditional structures are not reflected in the overall design of the river basin management and where deep social inequities persist.

From reviewing other sectors we find that the following aspects of initial conditions and history influence the efficiency and equity outcomes of decentralization and therefore steps must be taken to overcome any potential negative effects.

(1) First, we learned that gains from lower transactions costs when decisions are based on better local information are more likely in a large country setting rather than in a small one. In large federal systems such as in the United States and Brazil, considerable authority is devolved to the individual states, however, this seems counterproductive in small countries where regions or districts are not likely to have the necessary tax base (insufficient population and economic activity especially in agrarian economies) to support public services without dependence on central transfers. Decentralization is in fact, desirable in large countries because under central control districts are too remote from the center for adequate financial accountability in terms of how transferred funds have been spent. Further, the incentive to utilize local information is greater for decision makers at the lower levels than it is at the center.

In the Gambia, a relatively small country, delivery of health services was managed directly by the Ministry of Health and only recently are management teams being established in the regions to encourage more local decision-making (Mills et al., 1990). On the other hand, in larger countries, even control at the state level appears centralized to those at the grassroots. At the same time, hospital and other secondary health services require a large enough population base to support economically efficient service delivery. Hence, how many intermediate levels are essential to supervise, manage and provide effective primary health care services within available financial resources is a critical issue in the health sector.

In Chile, the health system has evolved so that there are four levels of management with distinct functions. State representatives, appointed by the Ministry of Health are positioned in 13 regions and 27 area health service centers, which in turn can transfer some management and primary health services to municipalities. Planning and policymaking are the main functions of the Ministry of Health. Directors appointed to regional levels and their offices carry out supervisory and administrative functions while the management and implementation of health care activities, comprising mainly curative and preventive services, is entrusted to the area health services. Since municipalities also handle other related tasks such as, housing and toilet facilities, unemployment benefits and educational facilities, it is considered useful to include primary health care also at that level. Further this brings the reach of health care to a level where there is better information of local needs and contribution from municipal funds (Montoya-Aguilar and Vaughan in Mills et al., 1990). But recalling the example of the municipality of El Bosque (see section 4.2 on healthcare), even this organization leaves less financially endowed municipalities strapped for funds (Gideon, 2001).

The issue of sufficient size (in an economic sense) is relevant for river basin management because the hierarchy of agencies that are set up may also have to depend on revenues and/or compete with other sectors for financial resources. In Indonesia, the Jatiluhur Authority (POJ) on the Citarum River Basin and the Brantas Basin Water Management Corporation (PJT) are underfunded to cope with their responsibilities. Income from urban and industrial water supply covers only $50 \%$ of their costs while the contribution from irrigation is minimal. Both corporations post budget surpluses around $10 \%$ to $15 \%$ by cutting down on their activities in order to be viewed as healthy agencies. While other factors such as tariffs set by the government and lack of access to outside lending contribute in part to their financing problems, it may be argued that size of the revenue base also has a role to play. The POJ has to compete for provincial and central subsidies while the PJT has to manage solely from revenues (Alaerts and Le Moigne, forthcoming). 
Other examples of river basin agencies that need a large enough revenue base to carry out their activities are: the Water Agencies in France that levy and collect pollution charges from water users in order to finance five-year programs for pollution control and other projects. The Tarim Basin Water Resources Protection Fund in the People's Republic of China is dependent on "water fees and penalty fees, and budget allocations from the central, regional and prefecture governments" in addition to a variety of loans and taxes (Alaerts and Le Moigne, forthcoming). In fact, as we learned in the Bicol River Basin (Philippines) case study, there is a danger of an ineffective river basin organization being viewed as an unnecessary drain on local financial resources, which could threaten its long term existence.

(2) History plays an important role in shaping the decentralization reform in the water resources sector. In the case of some African nations the impact of policies pursued by former colonial rulers has to be addressed if decentralization has to be successful especially with respect to equity issues. The problems arise from the former policy of access to water having been tied to land ownership where the owners are predominantly white farmers. One example is the Zimbabwean study by Derman et al (2000) already described in section 4.1. In that context, conversion of former water rights to water permits continues to marginalize small farmers and women despite the establishment of stakeholder associations.

Schur (2002) describes South Africa's new water pricing and access to irrigation water strategy as being designed to redress past imbalances that existed under the apartheid regime and at the same time to manage the water resources efficiently. Water service authorities are to receive 25 liters per capita per day free of charge to accommodate at least 18 million people without access to basic potable water. Previously disadvantaged farmers will be allowed access to irrigation water from Government Schemes through land reform. Other programs include concessionary periods when they will not be charged for the full cost of water whereas established schemes and commercial farmers will be subject to full cost recovery of $O \& M$ plus catchment costs.

Similarly, the role of history is evident in river basins. The hierarchy that manages the Aral Sea Basin today had to be reorganized to protect the interests of five independent nations (Uzbekistan, Kazakhstan, Turkmenistan, Tajikistan and the Kyrgyz Republic) all of which were part of the former Soviet Union. In the earlier situation, operation and maintenance of headwater infrastructure was handled by two federally funded basin organizations. Today, the Inter-State Commission for Water Coordination approves policy proposals for consideration by the International Fund for Saving the Aral Sea, comprising representatives from all five nations (Dukhovny and Sokolov in Alaerts and Le Moigne, forthcoming).

(3) Conditions that encourage cooperation among small groups are widely discussed in the decentralization literature (Bardhan, 1993; Wade, 1997; Ostrom, 1990). Tomosho, Fujimoto, and Yoshomura (2002) observe a "social dilemma" in the context of irrigators in the Lake Biwa area in Japan. Irrigation water pricing includes a volumetric component that is measured by a flow meter associated with each block of irrigated area which is managed by a farmer group. Here, in order to discourage individual farmers from feeling tempted to use more water than others in the block, farmers were kept informed about the differences in the water charges among blocks so as to encourage competition among them to reduce charges. The groups are further divided and kept within their living settlements in order to promote cohesiveness among the members of the group. This aspect is important in the integrated management of river basins especially if decisions at the lowest appropriate level are to be made via stakeholder dialogue and participation. Cooperation is also critical in coordinating upstream and downstream activities. The idea may even be extended to cooperation among riparian nations as is demonstrated by the countries in the Rhine River Basin in trying to contain chemical pollution levels through cooperative agreements (Huisman, Pieter in Alaerts and Le Moigne, forthcoming).

(4) Initial conditions also imply existing legislation, especially relating to property and water rights and institutions such as effective voting mechanisms at the local level. The issue of corruption and capture by local elite was covered at length in section 4.6 largely in the context of targeted assistance programs. The idea was also touched upon in describing the resistance by teachers' unions to 
control of their salaries, appointments, transfers, and promotions by non-professionals in the education sector. One of the key aspects of integrated river basin management is allocation of water rights and ensuring access to water for all users. Therefore, the possibility of capture of benefits by some groups must be addressed.

The issue takes on added significance because of the policy to recover costs, particularly those pertaining to operation and maintenance, management and delivery, and even capital investments such as irrigation infrastructure wherever possible. The only way to secure widespread acceptance of paying for services relating to water resources management for the benefit of all users is if those benefits actually reach all users. To begin with users have to be made aware of and educated about what their role as stakeholders in the water sector implies. Derman et al. (2000) observe that the vast "majority of Zimbabweans (as in most nations) are not politically active in the water arena" and the government takes on the role of protecting their interests. The mode of stakeholder participation has to be designed to ensure that the voices of those without significant property rights or permits are not lost.

In this respect, the importance of local institutions is stressed in the literature. Galasso and Ravallion (2000) find better targeting of the poor for assistance where cooperatives for farmers and landless laborers exist. Chattopadhyay and Duflo (2001) study the policy to reserve one-third of all candidacies for heads of village councils in India for women. They conclude, based on a district in West Bengal, that drinking water, fuel and roads are paid more attention when women leaders take the decisions. Further, participation by women was also greater when the leader of the council was a woman.

(5) The issue of capture is directly linked to the extent of economic inequality existing before the decentralization reform. The case studies of integrated river basin management in Brazil described earlier, illustrate how states differed in the way they took advantage of the National Water Policy and the National Water Resources Management Act. In particular, the uneven social structure in the São Francisco River basin (Ioris 2001) has accorded low priority to expand public irrigation on which the subsistence farmers depend during periods of drought relative to the storage structures catering to large landowners.

\section{Political leadership and commitment}

Political commitment to decentralization has many dimensions. It is imperative for the national government to clarify its position by decree or though the promulgation of laws. It is particularly useful to signal continuity in policy when governments change in quick succession. In the health sector, for example, decentralization is a slow process and sufficient time is needed for each phase to stabilize. Rapid changes in the national government, as was the case in Yugoslavia between 1946 and 1974, prevent follow-up measures from being carried out after the initial round of restructuring has been instituted, leading to uncertainty and having to retrace some steps already taken in a certain direction. Similarly, it is equally important for state or regional governments in a federal system to affirm their compliance or otherwise to indicate what local populations may expect. Political leadership is especially in focus when reforms are triggered by deteriorating conditions as was the case in some African nations (e.g., Benin, Zambia; see healthcare sector section 4.2) or in response to environmental pollution affecting the local economy as in the Murray-Darling Basin.

\section{Decentralization and subsidiarity}

While the main message that organization based on the subsidiarity principle is crucial for success is clear in all sectors reviewed, the problems with implementation are equally visible. It is evident from the experience of other sectors that strategies must focus on financing mechanisms and upgrading skills especially those relating to planning and management. For example, in a decentralized scenario in the road sector, local governments may be more successful with lowering resource costs if they are able to forge alliances, requiring persuading and negotiating skills, with neighboring districts in order to negotiate large scale contracts with private providers. Principals and teachers must be competent 
as educators but also as managers in school-based management, for instance. Since opportunities to train are few at the lower level, special attention has to be paid to training. The lesson here is that gains from devolution may only be expected after adequate capacity is built up and therefore, shifting authority at the appropriate time is a critical component in decentralization strategy.

Implementation based on the subsidiarity principle is also contingent upon transparency. This implies attention to three areas: (1) clear statement of objectives and commitment to them as against other unstated goals; (2) definition of roles and responsibilities that make practical sense; and (3) reliance on good quality information and data. Situations where supervisory roles are thrust upon positions with no legal authority to discipline those being supervised are common. In Botswana, the regional health teams find themselves supervising services and staff over whom they have no disciplinary authority. The role of the Catchment Manager in the water sector in Zimbabwe is equally ambiguous since the manager is accountable to the government ministry whereas the Catchment Councils that he/she oversees are accountable to stakeholders. Similar situations are illustrated in the Bicol case study where the entire river basin agency was bypassed by the local government agencies and in the Yellow River Basin where the YRCC is lower in rank than the provincial governments yet it has to supervise and coordinate their needs with those of the Ministry of Water Resources.

In the education sector we learned about the debate over whether politicians are competent enough to be in charge of policy (which in turn could influence even issues such as choice of curricula and text books traditionally left entirely to professionals). Although on the face of it this question may seem irrelevant to river basins, similar situations do appear in this sector also. For example, consider the contradiction in views between the YRCC and the central government with regard to the proposal to divert water from the Yangtze River in Southern China up to Beijing and surrounding areas. The question is are politicians at the center competent to take decisions that may affect river basins and their delicate ecological systems and how much authority do river basin authorities really have relative to central governments? Would it be sufficient for river basin authorities to merely play an advisory role in this context?

\section{Key implementation strategies: a summary}

Decentralization is multifaceted. As a consequence, the feasibility and success of decentralization depends on a variety of complementary actions. Thus, while technical considerations, such as, lowering transactions costs through better customer feed-back at the local level and evidence of declining scale economies in infrastructure sectors, form a core consideration in the desirability and success of decentralization, regulatory, administrative, political, and fiscal mechanisms need to evolve to support effective decentralization. All necessary aspects of decentralization usually have to work in tandem to make the decentralized system produce the desired results.

As we have seen above there are several factors that influence the outcome of the decentralization approach. However, it is possible to find some crucial areas that seem to be the stumbling blocks in all sectors. This paper identifies the following objectives to be most critical in implementation:

Devising mechanisms to overcome financial inadequacy. The reality is that the more economically well-off the area, the easier it is to mobilize resources both in terms of revenues and labor. Under these circumstances financial inadequacy can be overcome by devolution of fiscal authority to raise revenue through user fees, wherever feasible or alternative mechanisms. Further, this paves the way for local authority to budget which implies more flexibility in shifting funds to a service of more immediate concern locally. For example the energy sector in Chile requires all users, private companies, and the state to contribute to the financing of expansion projects. Other instruments such as matching grants and ear marked funds encourage financial responsibility provided they are used for the designated purpose in a transparent manner.

Incorporating training and creating opportunities to upgrade skills must be an integral part of all planning strategy. In addition, the need for data is equally significant. In some contexts, as in the health sector in Chile or in targeted assistance projects, the formulae for grants and transfers are based on the number of registered beneficiaries. The lack of accurate data results in underestimates of the levels of financing required for the programs. In the context of river basins, the survival of 
user associations and catchment councils depends on charges, such as levies on permits, collected from their members. Details about membership, farming activities, and the extent of water usage are some of the many kinds of data that are essential for smooth functioning.

Finding ways through reassignment in other areas, retrenching those who are ready to retire before others, and revision of pay scales among other means, to deal with resistance from entrenched staff and beneficiaries of the existing system

Ensuring sustainability of the new decentralized structure through stakeholder commitment is another significant factor. Uncertainty about whether the consultative process can sustain itself for the long term was illustrated in the case study on the water sector in Zimbabwe (Derman et al., 2000) Participants from communal areas have to travel long distances incurring costs for fares. Time is spent at meetings discussing claims for reimbursement of costs at the expense of focus on water issues.

While many aspects of the decentralization experience in other sectors are relevant for integrated river basin management, others are less easy to apply. For instance, intersectoral coordination is vital to both river basin management and healthcare. In the latter sector, matching the boundaries of health center jurisdictions to administrative boundaries of local governments is believed to be useful to facilitate intersectoral coordination. However, a similar solution is not likely to be feasible in river basins, especially those that cross state and national borders, because geographic boundaries rarely match those in political administration.

\section{CONCLUSIONS}

Decentralization in its various forms - technological, regulatory, administrative, political, and fiscalis being experienced in sectors such as electric power supply, roads, targeted assistance programs, health, education, and irrigation management. The challenge is to achieve and sustain the complex and complementary approaches to decentralization.

The twin objectives of improving efficiency in governance and increasing equity at local levels remain the unifying themes. To implement them the underlying principle common to all these sectors and to river basin management is that of subsidiarity, which argues that governance is more effective if the decision-making authority is located where the pertinent knowledge exists and where decisionmakers are directly responsible for the outcomes of actions taken to the community they serve.

The shift of authority from central government to lower levels is still in its early stages and it is not surprising that many issues have to be tackled before the new system shows the desired results. The decentralization process and experience in several sectors was reviewed in this report with a special focus on obstacles encountered in implementation.

The main conclusions of the literature survey come as a caution to anyone who believes that decentralization is, in itself, a solution to problems of inefficiency and inequity in developing countries. The report shows that the case for decentralization as against central control is not itself unambiguous. Central control offers distinct advantages in certain circumstances; there are tradeoffs and tensions to be reconciled (e.g., economies of scale versus local monitoring; integrated management or inter-regional equity versus local control).

Nonetheless, decentralization (in its various forms and degrees) holds out the promise of reduced financial and transaction costs, increased flexibility and efficiency, local control and accountability. But the evidence from a wider range of surveys and case studies that the report reviews for several sectors (education, healthcare, roads, irrigation, and public infrastructure services) suggests that the preconditions for effective decentralization are daunting, especially given the historical, political and socio-economic conditions facing many developing countries.

For example, successful decentralization depends on the regions or districts concerned having a large enough revenue base to undertake activities; it requires the existence of clearly defined property and water rights among potential stakeholders (for effective negotiation and commitment to operations and maintenance); it requires the socio-political pre-conditions for participation and the resistance of elite capture (e.g., unstratified social structures); and demands transparency, clear roles and responsibilities with legal authority, and quality information. For those anticipating that 
decentralization might solve problems associated with weak centers and fiscal constraints, it is salutary to learn that decentralization works bests in the context of strong central government and economically prosperous regions with a high education and skills base.

The case studies examined reveal the serious problems that occur when regulatory, administrative, political or fiscal mechanisms have not evolved sufficiently to support decentralization; or where skills accumulated in central bureaucracies are lost through retrenchment. More intractable still are factors of historical context and political leadership. Many of the factors affecting degrees of elite capture in decentralization, such as land rights, power inequalities, and political resistance, are not easily amenable to policy interventions.

The literature survey reveals that some debates, such as whether professional expertise is necessary to maintain minimum or desired standards in education, or of geographic boundaries in health system organization, are sector specific. However, others, such as the need for political and financial accountability, the related data requirements, and educating stakeholders and potential beneficiaries of the new system and how they can participate in it, are true of decentralization wherever it is to unfold.

In particular, this paper identifies four issues to be tackled that demand high priority. These are (1) devising ways to overcome financial inadequacy at the lower level; (2) making a commitment to incorporating opportunities to upgrade skills, particularly management skills, when designing programs while also ensuring that the expertise accumulated in central bureaucracies is not dissipated; simultaneously encouraging those facing retrenchment to contribute to the new systems wherever feasible; (3) assuring beneficiaries of the pre-reform structures, as with urban pharmacists in the African case studies (Hanson et al., 1997) or hydropower utilities in the Columbia-Snake River case study (Wandscneider, 1984), that their rights would be protected; and (4) planning to sustain a long-term commitment to the decentralization process as it is likely to be slow and drawn out, perhaps by demonstrating positive outcomes in a key element of the sector in question.

The survey finds these lessons to be highly relevant for integrated river basin management through decentralization because they constitute the nitty-gritty details of the broader criteria for success identified in the context of river basins, namely, initial conditions, political leadership, subsidiarity, transparency, and property rights. 


\section{REFERENCES}

Agarwal, A. and S. Narain. 1999. "Making Water Management Everybody's Business: Water Harvesting and Rural Development in India." Gatekeeper Series No. 87. London, U.K.: International Institute of Environment and Development.

Ahmad, Nasir. 1992. Decentralization: A Study into Forms Structures and Development Processes. (September). Peshawar: Pakistan Academy for Rural Development.

Akin, John, Paul Hutchinson and Koleman Strumpf. 2001. "Decentralization and Government Provision of Public Goods: The Public Health Sector in Uganda." Working Paper (March), The Measure Project, Carolina Population Center.

Alaerts, Guy J. 1999. "Institutions for River Basin Management: The Role of External Support Agencies (International Donors) in Developing Cooperative Arrangements," International Workshop on River Basin Management - Best Management Practices, Delft University of Technology/River Basin Administration (RBA), The Hague, October 27-29.

Alaerts, Guy and Guy Le Moigne (Editors). Forthcoming. Integrated Water Management at River Basin Level: An Institutional Development Perspective.

Alderman, Harold. 1998. "Social Assistance in Albania: Decentralized and Targeted Transfers." Living Standards Measurement Study Working Paper 134. Washington, D.C.: World Bank.

Bardhan, Pranab. 1993. "Analytics of the Institutions of Informal Coorperation in Rural Development." World Development, 21 (4) September.

Bardhan, Pranab. 1996b. "Decentralised Development." Indian Economic Review, 31 (2): p.139-156.

Bardhan, Pranab and Dilip Mookherjee. 1998. "Expenditure Decentralization and the Delivery of Public Services in Developing Countries." Working Paper, Berkeley CA, U.S.A.: Department of Economics, University of California.

Bardhan, Pranab and Dilip Mookherjee. 1999. "Relative Capture of Local and National Governments." Working Paper, Department of Economics, University of California, Berkeley.

Bardhan, Pranab and Dilip Mookherjee. 2000a. "Capture and Governance at Local and National Levels." AEA Papers and Proceedings, 90 (2, May): p.135-139.

Bardhan, Pranab and Dilip Mookherjee. 2000b. "Corruption and Decentralization of Infrastructure Delivery in Developing Countries." Mimeo, Boston MA, U.S.A.: Institute for Economic Development, Boston University.

Bardhan, Pranab and Dilip Mookherjee. 2001. "Decentralizing Anti-Poverty Program Delivery in Developing Countries.”Mimeo (Revised) March, Boston MA, U.S.A.: Institute for Economic Development, Boston University.

Barrow, Christopher J. 1998. "River Basin Development Planning and Management: A Critical Review," World Development, 26 (1): p.171-186.

Besley, Timothy and Stephen Coate. 1999. "Centralized versus Decentralized Provision of Local Public Goods: A Political Economy Analysis." NBER Working Paper Series 7084. Cambridge MA, U.S.A.: National Bureau of Economic Research. http://www.nber.org/papers/w7084

Bird, R.M. 1994. "Decentralization Infrastructure: For Good or for Ill?" World Bank Policy Research Working Paper No. 1258. Washington, D.C.: World Bank.

Bish, R, and V. Ostrom. 1973. Understanding Urban Government.

Bossert T., Beauvais J., and Bowser D. 2000. "Decentralization of Health Systems: Preliminary Review of Four Country Case Studies." Partnerships for Health Reform Major Applied Research 6 Technical Report 1,(January). (http://www.phrproject.com/publicat/arp/mar6tr1ab.htm)

*Cakmak, Erol H. 2002. "Pricing of Irrigation Water in Turkey." In http://www.worldbank.org/agadirconference

Castro, Jose Esteban. 1995. "Decentralization and Modernization in Mexico: The Management of Water Services,” Natural Resources Journal, 35 p.461- 487. 
Chattopadhayay, R. and E. Duflo. 2001. "Women as Policy Makers: Evidence from an India-Wide Randomized Policy Experiment." Unpublished Paper, Massachusetts Institute of Technology. *Chioccioli E., A. Hamdy, and C. Lacirignola. Not dated. "Institutional Capacity Building and Integrated Water Resources Management in the Mediterranean." Available on Website http://www.oieau.fr/ciedd/contributions/at2/contribution/ciheam.htm

Conyers, Diana. 1984. "Decentralization and Development: a Review of the Literature." Public Administration and Development (U.K.) 4 (April/June): p.187-197.

Cowie, Gail M. and Laurence J. O’Toole. 1998. "Linking Stakeholder Participation and Environmental Decision-making: Assessing Decision Quality for Interstate River Basin Management," Participation and the Quality of Environmental Decision Making. Coenen, Frans H.J.M., Dave Huitema, and Laurence J. O’Toole, Jr. (eds.) Dordrecht, The Netherlands: Kluwer Academic Publishers.

Davies, B. and G.C. Hentschke. 1994. "School Autonomy: Myth or Reality - Developing an Analytical Taxonomy." Educational Management and Administration 22(2) 96-103.

Derman, Bill., Anne Ferguson and Francis Gonese. 2000. "Decentralization, Devolution and Development: Reflections on the Water Reform Process in Zimbabwe." Draft \#3 (August 9), Centre for Applied Social Sciences, University of Zimbabwe.

DeStefano, J. 1996. Community-based Primary Education: Lessons Learned from the Basic Education Expansion Project (BEEP) in Mali. Washington, D.C.: United States Agency for International Development, Office of Sustainable Development.

Devas, N. 1997. "Indonesia: What do we Mean by Decentralization?" Public Administration and Development (U.K.) 17: p.351-367.

Dillinger, B. 1995. "Decentralization, Politics and Public Service," in A. Estache (ed.) Decentralization Infrastructure: Advantages and Limitations. World Bank Discussion Papers 290. Washington, D.C.: World Bank.

Dourojeanni, Axel. 1994. "Water Management and River Basins in Latin America," Cepal Review, 53 (August): p.111-128.

Dublin Statement. 1992. Dublin Statement on Water and Sustainable Development, U.N. International Conference on Water and the Environment, Jan. 26-31, 1992, reprinted in 22 ENVTL. POL'Y \& L. 54.

Elamon, Joy and B. Ekbal. 2000. "Health Sector Reforms and Local Level Planning-Experience of Kerala." International Conference on Democratic Decentralization 2000 May 23-27. Trivandrum, Kerala, India: State Planning Board, Kerala.

Estache, A., and Sarbajit Sinha. 1994. "Does Decentralization Increase Public Infrastructure Expenditure?” World Bank Policy Research Working Paper No. 1457. Washington, D.C.: World Bank.

Evans, Peter. 1996. "Government Action, Social Capital and Development: Reviewing the Evidence on Synergy." World Development 24 (6):p.1119-1132.

*Facon, Thierry. 2002. "Downstream of Irrigation Water Pricing - The Infrastructure Design and Operational Management Considerations." in http://www.worldbank.org/agadirconference

Fisman, Raymond and Roberta Gatti. 2000. "Decentralization and Corruption: Evidence Across Countries." World Bank Policy Research Working Paper No. 2290. Washington, D.C.: World Bank.

*Fontenelle, Jean-Philippe and Francois Molle. 2002. "The Intricacies of Water Pricing in the Red River Delta, Vietnam." In http://www.worldbank.org/agadirconference

Galasso, Emanuela and Martin Ravallion. 2000. "Distributional Outcomes of a Decentralized Welfare Program.” World Bank Policy Research Working Paper No. 2316. Washington, D.C.: World Bank. Ganesh, K.N. and C. Ramakrishnan. 2000. "Education and People's Planning Campaign - The Kerala Experience." International Conference on Democratic Decentralization 2000 May 23-27. Trivandrum, Kerala, India: State Planning Board, Kerala.

Ghai, Dharam and Jessica M.Vivian. 1992. Grassroots Environmental Action: People's Participation in Sustainable Development. London and New York: Routledge.

Gideon, Jasmine. 2001. "The Decentralization of Primary Health Care Delivery in Chile." Public Administration and Development (U.K.) 21 p.223-231. 
Govinda, R. 1999. "Reaching the Unreached Through Participatory Planning. School Mapping in Lok Jumbish" (India). Paris: UNESCO/International Institute for Educational Planning.

Greffe, Xavier. 1998. Decentralization and Local Infrastructure in Mexico: A New Public Policy for Development. Paris:Organisation for Economic Co-operation and Development.

*Hamdy, Atef. 2002. "Water Pricing in Agricultural Sector Charging Mechanisms and Implementation.” In http://www.worldbank.org/agadirconference

Hanson, E.M.1995. Best (and Worst) Practices in Educational Decentralization: the Cases of Venezuela, Colombia, Argentina and Spain. (World Bank Seminar on Education Decentralization 6): Washington, D.C.: World Bank.

Hanson, K., Hong, S. and Ian Hopwood. 1997. "Implementing Health Sector Reforms in Africa: A Review of Eight Country Experiences." UNICEF, Division of Evaluation, Policy and Planning Programme Division.New York: United Nations.

Humplick, F. and A. Estache. 1995. "Does Decentralization Improve Infrastructure Performance?" in A. Estache (ed.) Decentralization Infrastructure: Advantages and Limitations. Washington, D.C.: World Bank.

Humplick, F., and A. Moini-Araghi.1996a. "Is there an Optimal Structure for the Provision of Roads? (A Double Cost Level of Effort Approach to Decentralization of Road Provision)". World Bank Policy Research Working Paper No. 1657. Washington, D.C.: World Bank.

Humplick, F., and A. Moini-Araghi.1996b. "Decentralized Structures for Provision of Roads: A Cross-Country Comparison". World Bank Policy Research Working Paper No. 1658. Washington, D.C.: World Bank.

Ioris, Anotonia A. R. 2001. "Water Resources Development in the São Francisco River basin (Brazil): Conflicts and Management Perspectives," Water International 26 (1): p.24-39.

Isaac, Thomas T.M. 2000. "Campaign for Democratic Decentralisation in Kerala: An Assessment from the Perspective of Empowered Deliberative Democracy," International Conference on Democratic Decentralisation. Kerala State Planning Board, Thiruvananthapuram, India 23-27 May.

Jadresic, Alejandro. 2000 “A Case Study on Subsidizing Rural Electrification in Chile." Energy Service for the World's Poor 9: http://www.worldbank.org/html/fpd/esmap/energy_report2000/ch9.pdf

Johnson, Sam H., III. 1996. "Irrigation Management Transfer in Mexico: Moving Toward Sustainability." Paper prepared for the Internal Program Review, 1-2 April. Colombo: International Irrigation Management Institute.

Kemper, Karin E. and Douglas Olson. 2000. "Water Pricing: The Dynamics of Institutional Change in Mexico and Ceara, Brazil," p.339-357. Dinar, A. (ed.) The Political Economy of Water Pricing Reforms. New York: Oxford University Press.

Kleemeier, Elizabeth. 2001. "The Role of Government in Maintaining Rural Water Supplies: Caveats from Malawi's Gravity Schemes.” Public Administration and Development (U.K.) 21 p.245-257.

Kloezen, Wim. H. 1999. The Viability of Institutional Arrangements for Irrigation after Management Transfer in the Alto Rio Irrigation District, Mexico. Draft Report. Colombo: International Water Management Institute.

Koppel, Bruce. 1987. "Does Integrated Area Development Work? Insights from the Bicol River Basin Development Program," World Development, 15 (2): p. 205-220.

Lam, Wai Fung. 1996. "Institutional Design of Public Agencies and Coproduction: A Study of Irrigation Associations in Taiwan," World Development, 24 (6): p.1039-1054.

*Lebdi, Fethi; Hamdane, Abdelkader and Nicola Lamaddalena. 2002. "Water Management and Water Price Ananlysis in an Irrigation System managed by a Water Users' Association." In http://www.worldbank.org/agadirconference

Litvack, Jennie and Jessica Seddon. 1999. "Decentralization Briefing Notes." Working Paper,World Bank Institute. Washington, D.C.: World Bank.

Livingstone, I. And L. M. Assuncao. 1993. "Engineering vs. Economics in Water Development: Dam Construction and Drought in Northeast Brazil," Journal of Agricultural Economics 44: p.82-98. 
Lobo, Crispino and Thomas Palghadmal, 1999. "Kasare - A Saga of a People's Faith: A Case-study of Participatory Management." In Fertile Ground: The Impacts of Participatory Watershed Management, Hinchcliff, Fiona, John Thompson, Jules Pretty, Irene Gujit, and Parmesh Shah. London U. K.:Intermediate Technology Publications Ltd. p.247-258.

Lopez-de-Silanes, F., A. Shleifer, and R. W. Vishny.1995. "Privatization in the United States." Mimeo Cambridge Massacussetts: Harvard University.

Madelin, K.B. and C.C. Parkman. 1999. "A Review of Contract Maintenance for Roads." PLARC XXI World Road Congress. Paris: World Road Association (PIARC).

Malmberg, Calvo C. 1998. "Options for Managing and Financing Rural Transport Infrastructure." World Bank Technical Paper No. 411. Washington, D. C.: World Bank.

Malpica Faustor, C.N. 1994. Descentralizacion y planificacion de la educacion: experiencias recientes en paises de America Latina. Paris :UNESCO/International Institute for Educational Planning.

Mathew, George and Ramesh Nayak.1996. “ Panchayats at Work: What it Means for the Oppressed?” Economic and Political Weekly July 6 p.1765-1771.

McGinn, N. and T. Welsh. 1999. "Decentralization of Education: Why, When, What and How?" UNESCO: International Institute for Education Planning, Series Fundamentals in Educational Planning 64.

Merrey, Douglas J. 2000. "Creating Institutional Arrangements for Managing Water- Scarce River Basins: Emerging Research Results," Paper prepared for presentation at session on Enough Water for All, at the Global Dialogue on The Role of the Village in the 21st Century: Crops, Jobs, Livelihood, August 1517, 2000, EXPO 2000, Hannover, Germany.

Mestre, Eduardo R. J. 1997. "Integrated Approach to River Basin Management: Lerma-Chapala Case Study - Attributions and Experiences in Water Management in Mexico," Water International, 22 (3): p.140-152.

Mitchell, Bruce. 1990. Integrated Water Management: International Experiences and Perspectives. London and New York: Belhaven Press.

Mills, A., Vaughan, J. P., Smith, D.L. and Iraj Tabibzadeh. 1990. Health System Decentralization: Concepts, Issues and Country Experience. Geneva, Switzerland: World Health Organization.

Narayan, Deepa. 1995. The Contribution of People's Participation: Evidence from 121 Rural Water Supply Projects. Environmentally Sustainable Development Occasional paper Series No. 1. The World Bank, Washington, D.C.

Oorthuizen, Joost and Wim H. Kloezen. 1995. "The other side of the coin: A case study on the impact of Financial Autonomy on Irrigation Management Performance in the Philippines. Irrigation and Drainage Systems 9:15-37.

Ostrom, Elinor. 1990. Governing the Commons: The Evolution of Institutions for Collective Action. New York: Cambridge University Press.

Ostrom, Elinor. 1996. "Crossing the Great Divide: Coproduction, Synergy, Development," World Development, 24 (6): p.1073-1087.

Paterson, J. 1986. "Coordination in Government: Decomposition and Bounded Rationality as a Framework for "User Friendly" Statute Law," Australian Journal of Public Administration, 45 p.95-111.

Perris, L. 1998. "Implementing Education Reforms n New Zealand: 1987-97." Education Reform and Management Series, No.1.Washington, D.C.: World Bank.

Porto, Monica. 1998. "The Brazilian Water Law: A New Level of Participation and Decision Making," Water Resources Development, 14 (2): p.175-182.

PROBE. 1999. Public Report on Basic Education for India. New Delhi: Oxford University Press.

Prud'homme, R. 1994. "On the Dangers of Decentralization." World Bank Policy Research Working Paper No. 1252. Washington, D.C.: World Bank.

*Quassem, M. A. 2002. "Water Institutions-Bangladesh Experience." In http://www.worldbank.org/agadirconference

Rangeley, R., Thiam, B.M., Andersen, R.A., and C.A.Lyle. 1994. "International River Basin Organizations in Sub-Saharan Africa," World Bank Technical Paper No. 250. Washington, D. C.: World Bank. 
Rawal, Vikas.2000. "Non-Market Interventions in Water-Sharing: Case Studies from West Bengal." International Conference on Democratic Decentralization 2000 May 23-27. Trivandrum, Kerala, India: State Planning Board, Kerala.

Reynoso, Vincente Guerrero L.A.E. 2000. “Towards a New Water Management Practice: Experiences and Proposals from Guanajuato State for a Participatory and Decentralized Water Management Structure in Mexico," Water Resources Development, 16 (4): 571-588.

Robinson, Richard and David Stiedl. 2001. "Decentralization of Road Administration: Case Studies in Africa and Asia." Public Administration and Development (U.K.) 21 p.53-64.

Rodinelli, D. A. 1983. Implementing Decentralization Programmes in Asia: A Comparative Analysis. Public Administration and Development 3: p.181-207.

Rodinelli, D. and J. Nellis. 1986. "Assessing Decentralization Policies in Developing Countries: the Case for Cautious Optimism." Development Policy Review 4: p.3-23.

Romano, P.A. and E.A. Cadavid Garcia. 1999. "Policies for Water Resources Planning and Management of the São Francisco River Basin," A. K. Biswas, N.V. Corderio, B.P.F. Braga and C. Tortajada (eds.) Management of Latin American River Basins: Amaz̧on, Plata, and São Francisco. New York: United Nations University Press.

Salau, A.T. 1990. "Integrated Water Management: The Nigerian Experience," Integrated Water Manangement: International Experiences and Perspectives, p.188-202. Bruce Mitchell (ed.). London and New York: Belhaven Press.

Samad, M. and Douglas Vermillion. 1999. "An Assessment of the Impact of Participatory Irrigation Management in Sri Lanka," Water Resources Development, 15 (1/2): p.219-240.

*Schur, Michael. 2002. "Pricing of Irrigation Water in South Africa." In http://www.worldbank.org/agadirconference

Scudder, Thayer. 1989. "The African Experience with River Basin Development," Natural Resources Forum (May) p.139-148.

Shah, Anwar and Theresa Thompson. 2002. "Implementing Decentralized Local Governance: Treacherous Road with Potholes, Detours and Road Closures," forthcoming in Jorge MartinezVasquez (ed.) Proceedings of Can Decentralization Help Re-build Indonesia?

Sharma, R. 2003. "Kerala's Decentralisation - Idea in Practice," Economic and Political Weekly, September 6-12, XXXVIII (36): p.3832-3850. Mumbai, India: A Sameeksha Trust Publication.

Simpson, L.D. 1999. "The Rio São Francisco: Lifeline of the Northeast," Management of Latin Amercian River Basins: Amazon, Plata and São Francisco. A. K. Biswas, N.V. Cordeiro, B.P.F. Braga, and C. Tortajada (eds.) New York: United Nations University Press.

Solanes, Miguel. 1998. "Integrated Water Management from the Perspective of the Dublin Principles," Cepal Review, 64 (April): p.165-184.

Stoffberg, F.A., F.C. van Zyl, and B.J. Middleton. 1994. "The Role of Integtrated Catchment Studies in the Management of Water Resources in South Africa," Integrated River Basin Development, Celia Kirby and W.R. White (eds.), p. 455-462. Chichester, U.K.: John Wiley and Sons Ltd.

Subramanian, A., Jagannathan, V., and R. Meinzen-Dick.1997. "User Organizations for Sustainable Water Services." World Bank Technical Paper No. 354. Washington, D. C.: World Bank.

Tharakan, P.K.Michael. 2000. "Community Participation in School Education - Experiments and Experiences under People's Planning Campaign in Kerala." International Conference on Democratic Decentralization 2000 May 23-27. Trivandrum, Kerala, India: State Planning Board, Kerala.

Thomas, Craig W. 1999. "Linking Public Agencies With Community-Based Watershed Organizations: Lessons From California," Policy Studies Journal, 27 (3): p.544-564.

Tommasi, Mariano and Federico Weinschelbaum. 1999. A Principal-Agent Building Block for the Study of Decentralization and Integration. Mimeo, Universidad de San Andres.

Tomosho, T., Fujimoto, N. and A.Yoshomura. 2002. "A Case Study on Effects of a Water Saving Incentive to Water Users Associations.” In http://www.worldbank.org/agadirconference

Udofia, William E. 1988. "The Role of River Basins and Rural Development Authorities in the Development Process," Third World Planning Review, 10 (4): p.405-416. 
UNDP. 1992. United Nations Conference on Environment and Development, Rio de Janeiro: Agenda 21, Chapter 18: Protection of the Quality and Supply of Freshwater Resources: Application of Integrated Approaches to the Development, Management and Use of Water Resources. New York.

*Unver, Olcay and Rajiv K. Gupta. 2002. "Water Pricing: Issues and Options in Turkey." In http://www.worldbank.org/agadirconference

Vermillion, Douglas L. 1997. Impacts of Irrigation Management Transfer: A Review of the Evidence. Research Report 11, Colombo: International Irrigation Management Institute.

Visscher, Jan T., Peter Bury, Toby Gould and Patrick Moriarty. 1999. International Water Resource Management in Water and Sanitation Projects: Lessons from Projects in Africa, Asia and South America. IRC International Water and Sanitation Centre, Delft, The Netherlands.

Wade, Robert. 1997. "How Infrastructure Agencies Motivate Staff: Canal Irrigation in India and the Republic of Korea," in Infrastructure Strategies in East Asia, Ashoka Mody (ed.), Washington, D.C.: World Bank.

Wagley, Mohan P. 1999. "The Impact of Begnas Tal/Rupa Tal Watershed Management Project, Pokhara, Nepal." In Fertile Ground: The Impacts of Participatory Watershed Management, Hinchcliff, Fiona, John Thompson, Jules Pretty, Irene Gujit, and Parmesh Shah. London U. K.:Intermediate Technology Publications Ltd. p.164-177.

Walmsley, N. and N.J. Hasnip. 1997a. Case Studies for Water Resource Planning: Murray-Darling Basin (Australia). Department for International Development, Report OD/TN 89. Wallingford, U.K.:H R Wallingford.

Walmsley, N. and N.J. Hasnip. 1997b. Case Studies on Water Resource Planning: Lessons Learned and Keys to Success. Department for International Development, Report OD 138. Wallingford, U.K.:H R Wallingford.

Wandschneider, Philip R. 1984. "Managing River Systems: Centralization Versus Decentralization," Natural Resources Journal, 24 (October): p.1043-1066.

Wester, Philippus, Roberto Melville, and Sergio Ramos Osorio. 2000. "Institutional Arrangements for WaterManagement in the Lerma-Chapala Basin, Mexico," The Lerma-Chapala Watershed, Evaluation and Management. Kluwer Academic Publishers Monograph (forthcoming). Draft. Colombo: IWMI.

White, Gilbert. 1998. "Reflections on the 50-year International Search for Integrated Water Management." Water Policy 1 (1):p.21-27.

World Bank. 1993a. Water Resources Management: A World Bank Policy Paper. Washington, D.C. World Bank. 1993b. China Yellow River Basin Investment Planning Study. (June). Washington D.C. World Bank. 1994. Infrastructure for Development, World Development Report. Washington, D.C.: World Bank.

*Yazar, Attila. 2002. "Participatory Irrigation Management PIM in Turkey: A Case Study in the Lower Seyhan Irrigation Project.” In http://www.worldbank.org/agadirconference

Zusman, Eric. 1998. "A River Without Water: Examining Water Shortages in the Yellow River Basin," LBJ Journal of Public Affairs. Available on website http://uts.cc.utexas.edu/ journal/1998/river.html

*Some references are drawn from papers presented at the Conference on "Irrigation Water Policies: Micro and Macro Considerations, Agadir Morocco, June 15-17, 2002." All conference presentations can be found on: http://www.worldbank.org/agadirconference. 